ARTICLES

Submitted 11.19.2015. Approved 03.31.2016

Evaluated by double blind review process. Scientific Editor: Antônio Domingos Padula

DOI: http://dx.doi.org/10.1590/So034-759020160508

\title{
THE STATE OF RESEARCH ON CLEANER PRODUCTION IN BRAZIL
}

\author{
O estado da pesquisa sobre produção mais limpa no Brasil \\ El estado de la investigación sobre producción más limpia en Brasil
}

\begin{abstract}
The application of cleaner production (CP) practices in companies is not commonplace in Brazil. Moreover, there are significant difficulties in establishing partnerships among universities, companies, and the government. However, an increase in the number of companies concerned about the impacts of industrial activities on the environment has enabled the development of CP research. Hence, using a literature review and a bibliometric analysis to quantify the scientific production of $C P$, published in a congress promoted by the Journal of Cleaner Production in Brazil, and an analysis of social networks using UCINET-Draw, this study contributes to the current state of CP research in Brazil. Despite remarkable developments, shareholders and entrepreneurs still lack knowledge about the subsidies/funds to implement CP made available by the government, which would improve the implementation of CP practices. Moreover, university research programs may help companies to generate innovations in this field. This study is one of the first to review CP practices in Brazil, and proposes a framework to promote CP practices in Brazil.
\end{abstract}

KEYWORDS | Cleaner production, bibliometric analysis, UCINET-Draw, sustainable production and consumption, participation of universities, enterprises, and governments in research.

\section{RESUMO}

A aplicação da produção mais limpa (PML) em empresas não é prática comum no Brasil. Além disso, há dificuldades significativas para o estabelecimento de parcerias entre universidades, empresas e o governo. Entretanto, um aumento no número de empresas preocupadas com os impactos das atividades industriais no meio-ambiente tem permitido o desenvolvimento de pesquisas sobre PML. Assim, utilizando uma revisão de literatura e uma análise bibliométrica para quantificar a produção científica sobre PML, publicadas em um congresso promovido pelo Journal of Cleaner Production no Brasil, e uma análise de redes sociais, com a utilização do UCINET-Draw, este estudo contribui para o estado atual da pesquisa sobre PML no Brasil. Apesar de notáveis avanços, ainda falta aos acionistas e empreendedores conhecimento sobre os subsídios/fundos disponibilizados pelo governo para a implementação da PML, os quais melhorariam a implementação de práticas de PML. Além disso, programas de pesquisa universitária podem ajudar as empresas a gerar inovações neste campo. Este estudo é um dos primeiros a revisar práticas de PML no Brasil, e propõe uma estrutura para promover práticas de PML no Brasil.

GERALDO CARDOSO OLIVEIRA NETO geraldo.prod@gmail.com Professor at Universidade Nove de Julho, Programa de Mestrado em Engenharia de Produção - São Paulo -SP, Brazil

\section{FÁBIO YTOSHI SHIBAO \\ fabio.shibao@gmail.com Professor at Universidade Nove de Julho, Programa de Mestrado Profissional em Administração - Gestão Ambiental e Sustentabilidade - São Paulo - SP, Brazil}

\section{MOACIR GODINHO FILHO}

moacir@dep.ufscar.br Professor at Universidade Federal de São Carlos, Departamento de Engenharia da Produção - São Carlos - SP, Brazil

PALAVRAS-CHAVE I Produção mais limpa, análise bibliométrica, UCINET-Draw, produção e consumo sustentáveis, participação de universidades, empresas e governos em pesquisas.

\section{RESUMEN}

La aplicación de prácticas de producción más limpia $(C P)$ en compañías no es habitual en Brasil. Además, existen dificultades significativas para establecer alianzas entre universidades, compañias y el gobierno. Sin embargo, un aumento de la cantidad de compañías preocupadas con los impactos de las actividades industriales en el medio ambiente ha permitido el desarrollo de la investigación de CP. Por consiguiente, usando una revisión bibliográfica y un análisis bibliométrico para cuantificar la producción científica de CP, publicados en un congreso promovido por el Journal of Cleaner Production en Brasil, y un análisis de las redes sociales utilizando UCINET-Draw, el presente estudio contribuye al estado actual de la investigación de CP en Brasil. A pesar de los notables acontecimientos, a los accionistas y emprendedores aún les falta conocimiento sobre los subsidios/fondos para implementar CP ofrecidos por el gobierno, lo que mejoraría la implementación de prácticas de CP. Además, los programas universitarios de investigación pueden ayudar a las compañías a generar innovaciones en este campo. Este estudio es uno de los primeros en reseñas prácticas de CP en Brasil y propone un marco para promover las prácticas de CP en Brasil.

PALABRAS CLAVE I Producción más limpia, análisis bibliométrico, UCINET-Draw, producción y consumo sostenibles, participación de universidades, empresas y gobiernos en investigación. 


\section{INTRODUCTION}

Intense global competition and a rapidly changing business environment have encouraged enterprises to search for new ways to obtain a competitive advantage. Moreover, in order to minimize the impacts on the environment, many companies have changed their production processes, which has made research on cleaner production (CP) possible.

According to The United Nations Environment Programme, $\mathrm{CP}$ is defined as the continuous application of an integrated preventative environmental strategy to processes, products, and services to increase efficiency and reduce risks to humans and the environment (UNIDO, 2015).

This concept emerged in response to the need to disseminate information on sustainable development to enterprises, government agencies, and the academic community so that the impact of industrial activities on ecosystems could be understood and minimized. This understanding aids the identification and resolution of the problem of wasted raw materials in manufacturing processes. CP must be included in manufacturing processes in order to reduce emissions and to promote the use of resources in an eco-efficient manner (Glavič \& Lukman, 2007).

CP was initially introduced in Brazil in 1995 through the creation of the National Center for Clean Technologies (CNTL). The Brazilian Network subsequently supported the Center in order for CP work centers to be installed in all Brazilian states (Pereira \& Sant'Anna, 2012).

$\mathrm{CP}$ analyzes aspects related to the operation of a business and identifies opportunities for improvement, in terms of both economic and environmental performance (Khan, 2008).

Works that use bibliometric, meta-analyses, content analyses, and systematic reviews related to $\mathrm{CP}$ stakeholders include methanol production, sustainable development, similarities and differences in the concept of $C P$, carbon dioxide reuse in the production of leather, and barriers and CP strategies. Staniskis (2012) conducted analysis in different cases of researches carried out in Austria, Bulgaria, Estonia, Lithuania and Spain, denoting that the best results can be achieved when all stakeholders work together to implement sustainable production and consumption. However, seeking stakeholder's cooperation in environmental and economic practices is a challenge.

Riaz, Zahedi, and Klemes (2013) reviewed how CP is used in the methanol production process. The main purpose was to highlight the problems associated with the production of methanol, as well as to comply with the efforts of scientists and researchers to overcome these problems using modeling and optimization. Furthermore, they discussed the environmental benefits of methanol in reducing carbon dioxide $\left(\mathrm{CO}_{2}\right)$. Their findings indicate that methanol can increase consumption when mixed with fuel gas. Fluidized bed reactors, membrane reactors, and thermally coupled reactors are more viable, and have the potential to contribute to $C P$.

Karatzoglou (2013) compiled a literature review of education for sustainable development from articles published between 2003 and 2011. The results showed that CP is an excellent strategy for sustainable development. The most relevant journals were the Journal of Sustainability in Higher Education and the Journal of Cleaner Production, which included case studies.

Sangwan and Mittal (2015) reviewed green manufacturing and similar structures in order to trace the origin, definitions, scope, similarities, and differences of green manufacturing; environmentally conscious manufacturing; environmentally responsible manufacturing; environmentally benign manufacturing; sustainable manufacturing; clean manufacturing; cleaner production; and sustainable production with reference to the triple bottom line, product life cycle engineering, the systems approach, resource and energy efficiency, supply chains, and pollution prevention. Their results showed the need for standardization, because the aforementioned terms are not used consistently as concepts. In general, these terms focus on the life cycle, formulating end-of-life strategies, including the overall supply chain, and integrating environmental improvement strategies with business strategies.

Deng, Chen, Huang, Hu, and Chen (2015) reviewed carbon dioxide deliming in leather production, and proposed reusing carbon dioxide by means of available absorption and desorption technologies, which reduces occupational safety risks, regenerates new resources, and leads to CP. Moreover, they give an overview of the fundamentals, process optimization, occupational safety, and possible ways forward for carbon dioxide deliming in leather, and provide useful information to researchers and engineers in this field. Then, Hu and Deng (2016) conducted a literature review on the application of supercritical carbon dioxide in leather processing, and found opportunities to use carbon dioxide as a potential alternative solution for the CP of leather.

Vieira and Amaral (2016) conducted a survey to identify why CP is not widely adopted based on a systematic review of 37 articles distributed between 1994 and 2014. Their findings showed that regulations need to be more than simply a legal requirement, and must be seen as an opportunity for improvement. In addition, they identified characteristics that must be emphasized in methodologies and tools that can help in the execution of CP programs. These characteristics are related to culture, policies, methodologies adopted, education, and a lack of social pressure. It is necessary to promote the dissemination of knowledge and 
commitment within the entire chain of businesses, academics, governments, and the community.

Chang, Wu, Qiao, and Zhang (2015) used a spatial and temporal analysis to show the geographical characteristics, regional differences, time variations, and industry allocations of CP development in China. In addition, they emphasized the implementation of $C P$ in various industries to further demonstrate the regional characteristics of CP development in China. Finally, they proposed suggestions to promote the use of CP management systems for future CP development in China. The above findings indicate many deficiencies and gaps. With regard to the gaps, possible actions and measures include the following. First, to perfect the institutional system, it is necessary to institute supporting and supplemental regulations and policies in order to enhance the pertinence, compulsion, and enforceability of laws and provisions and to increase the applicability of CP to industries. In addition, it is highly recommended that $\mathrm{CP}$ be integrated with environmental management. Second, to improve administrative management, it is necessary to refine the scope of work for government agencies and to establish collaborative procedures and coordinating mechanisms between government departments, such as the environmental protection bureau, the competent authority of the industrial sector, and funding management agencies. Third, to expand China's funding sources, it is necessary to institute policies that encourage the use of $C P$, including emission reduction incentives, $C P$ subsidies, tax exemptions and reductions, and bank financing. Fourth, it is necessary to improve the technical capacity, including regular training sessions, annual performance evaluations, and the development of a professional qualification certificate system. It is also necessary to regularly compile and publish reports on CP case analyses in order to facilitate the dissemination of knowledge and technologies. Fifth, to enhance system acceptance, it is important to develop personnel so that they may qualify as experts. Moreover, it is crucial to constantly promulgate updated technical guidelines for industrial sectors in order to direct CP implementations. Sixth, to increase the number of research projects, it is necessary to increase the funding for such projects, including regulations, policies, institutions, methodologies, and technical guidelines. Furthermore, public participation needs to be promoted to develop a platform of information disclosure to broadcast new laws, regulations, and provisions in a timely manner, as well as to share experiences. Therefore, although CP development in China is generally increasing, there are clear geographically significant differences across regions, with considerable disparity in industrial allocation, especially for key enterprises, owing to government initiatives. Thus, it would beneficial to CP development in China if regionalized CP management systems were established and operated based on key geographical features, regional differences, and allocations among the various industries.

We were not able to find any literature that promotes improvements in the state of CP research in Brazil. Our results enable us to discuss the current state of such research in Brazil, and to suggest ways in which it can be improved and to present the possible consequences of making such changes. Therefore, this study serves as a guide for future Brazilian research on this topic.

The Journal of Cleaner Production (JCP) has published many articles on CP (Karatzoglou, 2013). Moreover, it promotes and assists various workshops around the world to develop CP research. Another relevant aspect is that, every two years, the journal conducts the International Workshop on Advances in Cleaner Production (IWACP), in which the JCP chief editor launches a special volume to boost national and international submissions for the journal.

Thus, the research question addressed in the present research is as follows: How do we improve the state of $C P$ research in Brazil?

Based on this question, this research aims to achieve the following objectives:

- $\quad$ To identify the main thematic research on CP in Brazil

- $\quad$ To identify the most used research methods when investigating CP in Brazil

- $\quad$ To identify which business segments have adopted $\mathrm{CP}$ in Brazil

- To understand the relationship among universities, the government, and enterprises in terms of CP research in Brazil.

This article is organized as follows. Next sections present the research procedures, our results and analysis, and the discussion of the results. Last section concludes the article.

\section{Research procedures}

The research procedure consists of a bibliometric analysis to quantify the scientific production (Cooper \& Lindsay, 1998). According to Pilkington and Meredith (2009) and Hassan, Haddawy, and Zhu (2013), a bibliometric analysis is relevant to indicating directions and strategies for future studies. 


\section{Data collection}

First, we perform a literature review of bibliometric studies and bibliometric reviews on the research topic of the present study. In this phase, "ProQuest," "EBSCO," "JSTOR," and "Google Scholar" were researched for the period April 2013 to July 2013. The researched articles included the following keywords (in the title, keywords, or abstract): "bibliometric" and "cleaner production," "bibliometric" and "environmental," "bibliometric" and "sustainable production" and "bibliometric" and "sustainable manufacturing." Based on this search, we identified 42 articles from which the constructs of the present study could be proposed, as follows: the main thematics; business segments studied; research methods employed; and author affiliations, which can be specified as university, government, enterprise, or country.

Next, 512 articles published on the proceedings of the JCP congress of 2007, 2009, 2011, and 2013 were identified. A systematic analysis of the content of these papers was performed to identify their research constructs and to codify the data in a Microsoft Excel spreadsheet. The content analysis performed in this study is a source document that represents the content of these documents for the inference of knowledge through a set of operations (codification, categorization) (Bardin, 1986). The document analysis of the 512 articles lasted approximately 10 months, after which the data were codified and extracted from the articles and categorized based on the constructs. Data collection was performed and conferred upon by three researchers in an independent manner to minimize errors and prejudice (Hayes \& Krippendorff, 2007).

\section{Building the basis of our constructs: Bibliometric stu- dies found in literature}

For this study, we identified 42 articles that performed bibliometric studies in the environmental area. The main goal of this review was to select the basis for the constructs of the present study. The variables were chosen because they were found in the 42 articles related to bibliometric CP studies.

Of the 42 papers, 20 are based on thematics, in which publications are evaluated based on the primary subject of the articles. According to Leonidou and Leonidou (2011), the analysis of thematics seeks to identify the primary subjects, making it possible to suggest directions for future studies and to assess the knowledge of a specific thematic (Barrios, Borrego, Vilaginés, Ollé, \& Somoza, 2008). The subjects studied by the authors included the following: technology, knowledge, science, and evolution and policy (Radosevic, 2008); competitive advantage and sustainable supply chains (Brito \& Berardi, 2010); green supply chains (Brito \& Berardi, 2010; Jung, 2011; Rocha, Rocha, Rosa, Camargo, Zamberlan, \& Gomes, 2013); sustainability (Avila, Madruga, Zamberlan, \& Barros, 2013; Rocha et al., 2013); environmental management (Leonidou \& Leonidou, 2011); sustainable innovation (Kneipp, Rosa, Bichueti, Madruga, \& Schuch, 2011); design processes and design cognition (Chai \& Xiao, 2012); environmental disclosure and environmental accounting (Rosa, Ensslin, Ensslin, \& Lunkes, 2012a); and water (Avila et al., 2013).

An analysis of universities identified the teaching institutions affiliated with the authors published in the events, congresses, and conferences, as well as their relationships. According to Du, Wei, Brown, Wang, and Shi, (2013), an analysis of universities identifies the teaching institutions that produced the most articles per country on a specific thematic. Yarime, Takeda, and Kajikawa (2010) comment that various attempts have been initiated to create global systems of research collaboration among universities in order to improve the quality of studies. The country analysis seeks to identify the origins of the universities affiliated with the published authors. According to Machado, Manfrin, Lima, Silva, and Maciel (2012), a country analysis consists of identifying the geographic locations of the universities through the author affiliations. Yarime et al. (2010) note that an analysis of countries includes international collaborations within a specific thematic, which can be effective for sharing existing regional knowledge. In general, the works studied from this perspective, associated universities with analyses by country.

The results showed that an article addressing the thematic of eco-design analyzed 2,978 publications, and that the Delft University of Technology was the most prolific, with 85 publications (Boks, Stevels, \& Koster, 2001). A study on sustainable development identified 304 different universities in 53 countries, with an emphasis on 16 universities: 12 located in the United States, 2 in Canada, 1 in England, and 1 in Australia (Wright \& Pullen, 2007). Another study on research technology, knowledge, science, and evolution and policy identified the degree of concentration of these articles as 35\% in universities in the United States, and $20 \%$ in universities in developing countries (Radosevic, 2008). When addressing sustainability, US universities published $27 \%$, and UK universities published 11\% (Yarime et al., 2010).

In analyzing the assessment of the environmental impact, it was observed that there was a significant increase in the number of publications, from five articles in 1973 to 250 in 2009 (Yanhua, Song, Hongyan, \& Beibei, 2011). With regard to sustainable innovation, the United States published the most articles (236), and Sweden published the least (33). From this, we inferred that the institutions that published the most are found in 
countries that invest in research (Kneipp et al., 2011). With regard to sustainability, renewable energy, and the environment, it was observed that 40 universities produced more than 50 articles, with The Technical University of Denmark being the most productive (Romo-Fernández, Guerrero-Bote, \& Moya-Anegón, 2012). The article identified the United States (30\%) and the UK (20\%) as the countries that published the most, and Asia (10\%) and Oceania (10\%) as the regions that published the least (Chai \& Xiao, 2012). With regard to environmental disclosure, it was observed that the University of the Witwatersrand (47) published the most, and the University of Western Ontario (14) published the least, while the United States (560) published the most and Iran (29) published the least (Rosa et al., 2012a). A study on performance measurement identified that the United States (66) published the most articles, and Italy (8) published the least (Taticchi, Tonelli, \& Pasqualino, 2013). With regard to green supply chain management, the University Kassel (9) published the most articles, and Dalian University Technology (4) published the least. Then, the country with the most publications was the United States (81), while Brazil (7) had the fewest publications (Rocha et al., 2013). With regard to water, it was found that the Commonwealth Scientific and Industrial Research Organization (CSIRO) (154) was the university with the most publications, while Cornell University (34) was 25 in the list. Here, the United States $(1,234)$ published the most articles, followed by Australia (532) (Avila et al., 2013).

Finally, with regard to energy efficiency, the University of California, Berkeley, USA (142), published the most articles, while Oak Ridge National Lab, USA (32), published the least. Of the universities that published the most articles, two were American, six were Asian, one was European and one was Brazilian. Furthermore, the United States $(1,799)$ published the most articles, and Italy (201) published the least (Du et al., 2013).

In the studied works, seven bibliometric studies that analyzed the research methods used in the publications were identified. The analysis of the publication methods enables us to rank the methodological procedures used and to conduct a relational analysis. According to Leonidou and Leonidou (2011), the method of analysis consists of evaluating whether the studies showed greater consistency in their results. The articles were on the thematics of environmental management (Leonidou \& Leonidou, 2011), life cycle analyses (Costa \& Boente, 2012), and sustainability operation management (Machado et al., 2012). For the thematics, a greater use of exploratory research and a low incidence of literature reviews were found. With regard to the thematics of corporate social responsibility (Bakker, Groenewegen, \& Hond, 2005) and environmental accounting (Rosa et al., 2012b), the most common method was the literature review, while descriptive studies were least common. For the thematic of ecological economics, a trend toward empirical methods (42\%) was noted (Silva \& Teixeira, 2011). For the thematic of responsible procurement, quantitative research was the most used method (35.10\%), and descriptive studies were the least used (4.8\%) (Hoejmose \& Adrien-Kirby, 2012).

Of the researched studies, five bibliometric studies analyzed government agencies. A bibliometric analysis of government agencies seeks to identify participation and the relationships in articles published by entities of the government in congresses, conferences, and so on. The analysis of government agencies in bibliometric studies permits the identification of government participation in sustainability practices (Romo-Fernández et al., 2012). The articles showed that government agencies published more than universities when studies published in the primary congresses were considered (Boks et al., 2001). With regard to technology, knowledge, science, and evolution and policy, the results of government policies were limited when there were no organizers in the university, enterprise, and government relationships (Radosevic, 2008). For sustainability, renewable energy, and the environment, $22 \%$ articles were published by government agencies (Romo-Fernández et al., 2012).

Four bibliometric studies on business constructs were identified. Bibliometric analyses that focus on business seek to identify the participation of companies in research and their relationships in articles published in congresses, conferences, and so on. According to Boks et al. (2001), the participation of enterprises in scientific articles in the environmental area consists of evaluating whether the enterprises are promoting and allowing research on sustainability practices in production. The articles mention eco-design, which refers to enterprises that produce their own publications (6\%) (Boks et al., 2001). With regard to technology, knowledge, science, and evolution and policy, this method identified that innovation is successful when enterprises participate in research (Radosevic, 2008). With regard to the green supply chain, the regulatory pressure of the market is the predominant focus in the relationship between the enterprise and stakeholders (41\%), followed by the objectives of improving the economic and environmental performance (30\%) (Brito \& Berardi, 2010).

Only one study that performed a bibliometric study of business segments of enterprises was identified. According to Rocha et al. (2012b), analyses of the business segments of enterprises consists of understanding which business segments participated in studies in published articles, for example, when sustainability is studied in the mining industry segment.

Exhibit 1 shows the constructs used in the bibliometric studies found in the literature. 
Exhibit 1. Bibliometric reviews found in the present study

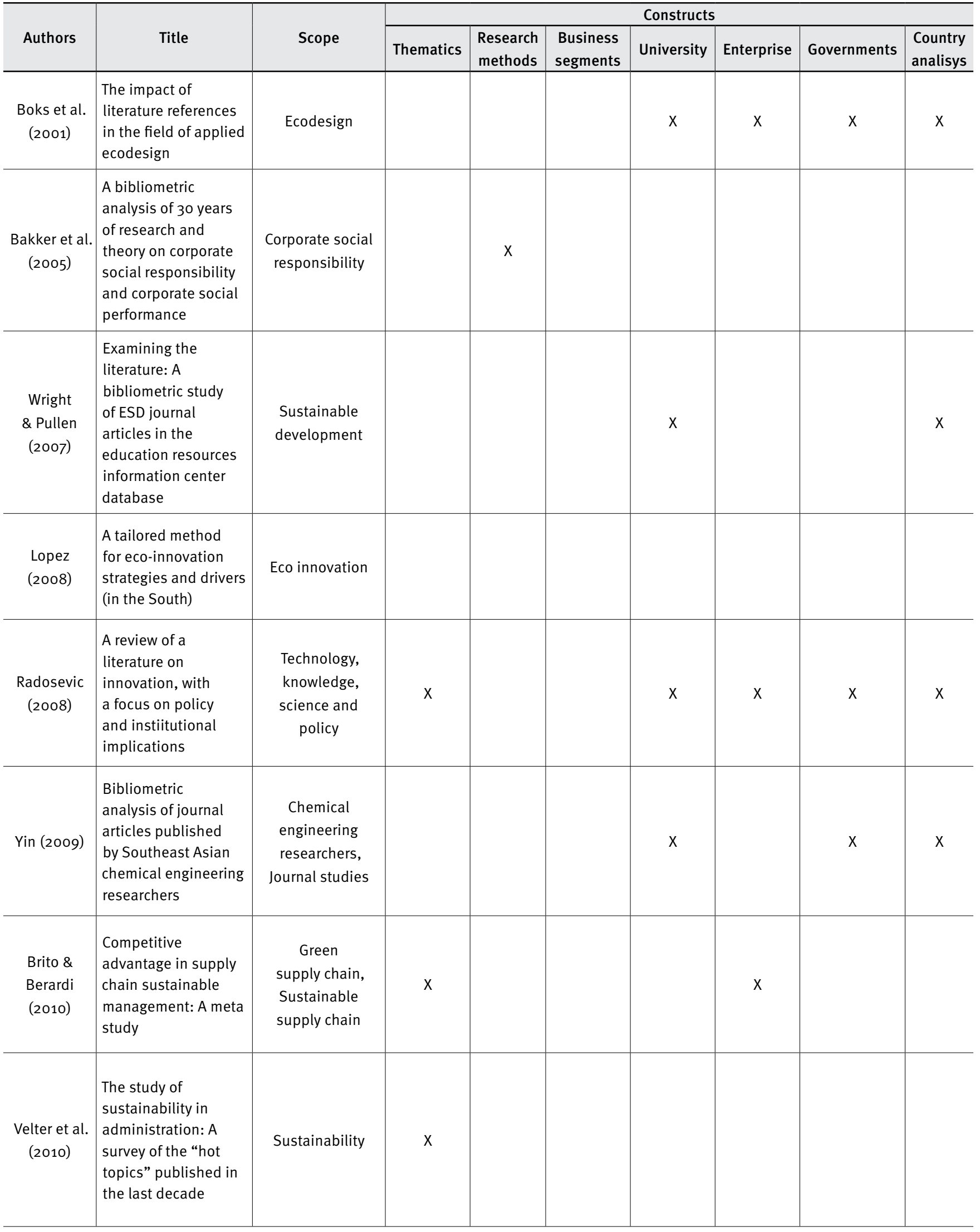


Exhibit 1. Bibliometric reviews found in the present study

(continuation)

\begin{tabular}{|c|c|c|c|c|c|c|c|c|c|}
\hline \multirow[b]{2}{*}{ Authors } & \multirow[b]{2}{*}{ Title } & \multirow[b]{2}{*}{ Scope } & \multicolumn{7}{|c|}{ Constructs } \\
\hline & & & Thematics & $\begin{array}{l}\text { Research } \\
\text { methods }\end{array}$ & $\begin{array}{l}\text { Business } \\
\text { segments }\end{array}$ & University & Enterprise & Governments & $\begin{array}{l}\text { Country } \\
\text { analisys }\end{array}$ \\
\hline $\begin{array}{l}\text { Yarime et al. } \\
\text { (2010) }\end{array}$ & $\begin{array}{l}\text { Towards institutional } \\
\text { analysis of } \\
\text { sustainability } \\
\text { science: A } \\
\text { quantitative } \\
\text { examination of the } \\
\text { patterns of research } \\
\text { collaboration }\end{array}$ & Sustainability & & & & $x$ & & & $x$ \\
\hline $\begin{array}{c}\text { Banchieri et } \\
\text { al. (2011) }\end{array}$ & $\begin{array}{l}\text { What has been said, } \\
\text { and what remains to } \\
\text { be said, about the } \\
\text { balanced scorecard? }\end{array}$ & $\begin{array}{l}\text { Balanced } \\
\text { scorecard }\end{array}$ & & & & & & & \\
\hline Jung (2011) & $\begin{array}{l}\text { A bibliometric } \\
\text { analysis on green } \\
\text { supply chain } \\
\text { management: } \mathrm{A} \\
\text { preliminary result }\end{array}$ & $\begin{array}{l}\text { Green supply } \\
\text { chain }\end{array}$ & & & & & & & \\
\hline $\begin{array}{c}\text { Kneipp et al. } \\
\text { (2011) }\end{array}$ & $\begin{array}{l}\text { Emergency of } \\
\text { the sustainable } \\
\text { innovation thematic: } \\
\text { An analysis of } \\
\text { sicentific production } \\
\text { through Web of } \\
\text { Science base }\end{array}$ & $\begin{array}{c}\text { Innovation } \\
\text { Sustentabilidade }\end{array}$ & $x$ & & & $x$ & & & $X$ \\
\hline $\begin{array}{l}\text { Leonidou \& } \\
\text { Leonidou } \\
\text { (2011) }\end{array}$ & $\begin{array}{l}\text { Research into } \\
\text { environmental } \\
\text { marketing/ } \\
\text { management: A } \\
\text { bibliographic } \\
\text { analysis } \\
\end{array}$ & $\begin{array}{c}\text { Environmental } \\
\text { management }\end{array}$ & $x$ & $X$ & & & & & \\
\hline $\begin{array}{l}\text { Manfrin et } \\
\text { al. (2011) }\end{array}$ & $\begin{array}{l}\text { Sustainability: The } \\
\text { evolution of the } \\
\text { theme in operations } \\
\text { management - a } \\
\text { literature review }\end{array}$ & $\begin{array}{l}\text { Sustainability, } \\
\text { Operations } \\
\text { Management, } \\
\text { Social Networks }\end{array}$ & $x$ & & & & & & \\
\hline $\begin{array}{l}\text { Pereira et al. } \\
\qquad(2011)\end{array}$ & $\begin{array}{l}\text { Socio-environmental } \\
\text { sustainability: A } \\
\text { bibliometric study } \\
\text { on the evolution of } \\
\text { the concept in the } \\
\text { area of operations } \\
\text { management }\end{array}$ & Sustentaibility & $x$ & & & & & & \\
\hline $\begin{array}{l}\text { Romo- } \\
\text { Fernández } \\
\text { et al. (2011) }\end{array}$ & $\begin{array}{l}\text { Analysis of Europe's } \\
\text { scientific production } \\
\text { on renewable } \\
\text { energies }\end{array}$ & $\begin{array}{c}\text { Renewable } \\
\text { energy, Europe }\end{array}$ & & & & $x$ & & & $x$ \\
\hline $\begin{array}{c}\text { Silva \& } \\
\text { Teixeira } \\
\text { (2011) }\end{array}$ & $\begin{array}{l}\text { A bibliometric } \\
\text { account of the } \\
\text { evolution of EE in the } \\
\text { last two decades Is } \\
\text { ecological economics } \\
\text { (becoming) a post- } \\
\text { normal science? }\end{array}$ & $\begin{array}{l}\text { Ecological } \\
\text { economics }\end{array}$ & $x$ & $x$ & & & & & \\
\hline
\end{tabular}


Exhibit 1. Bibliometric reviews found in the present study

(continuation)

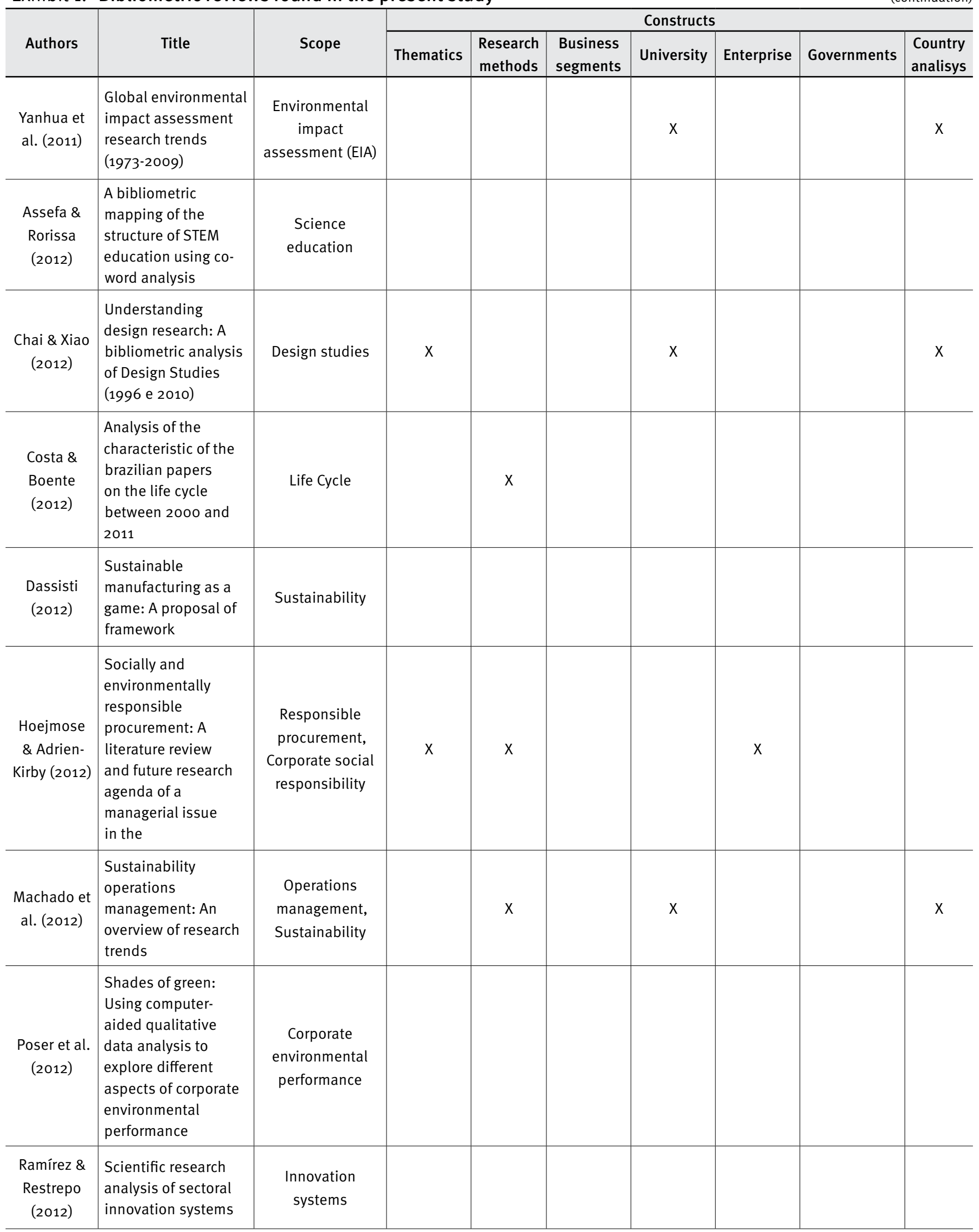


Exhibit 1. Bibliometric reviews found in the present study

(continuation)

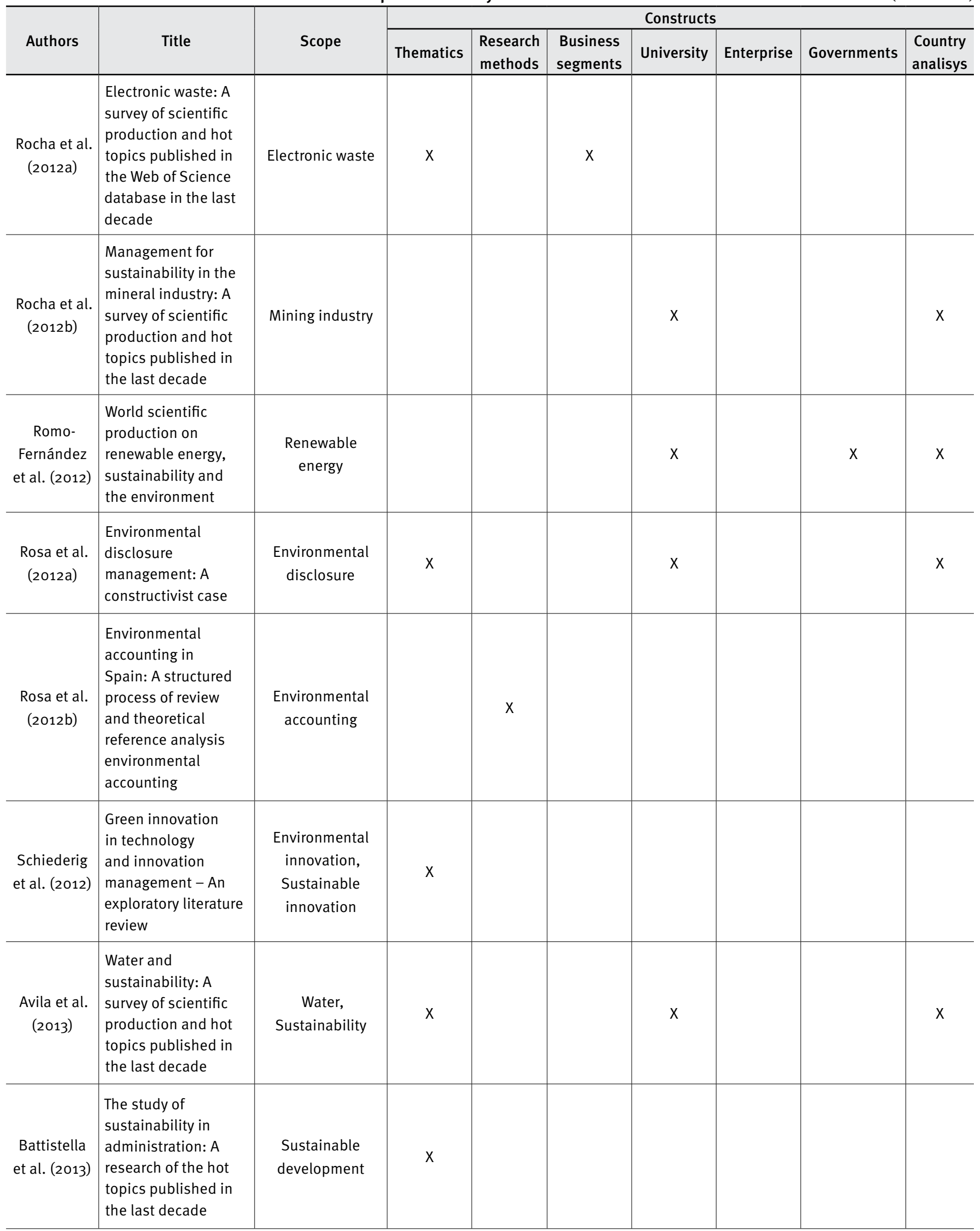


Exhibit 1. Bibliometric reviews found in the present study

(continuation)

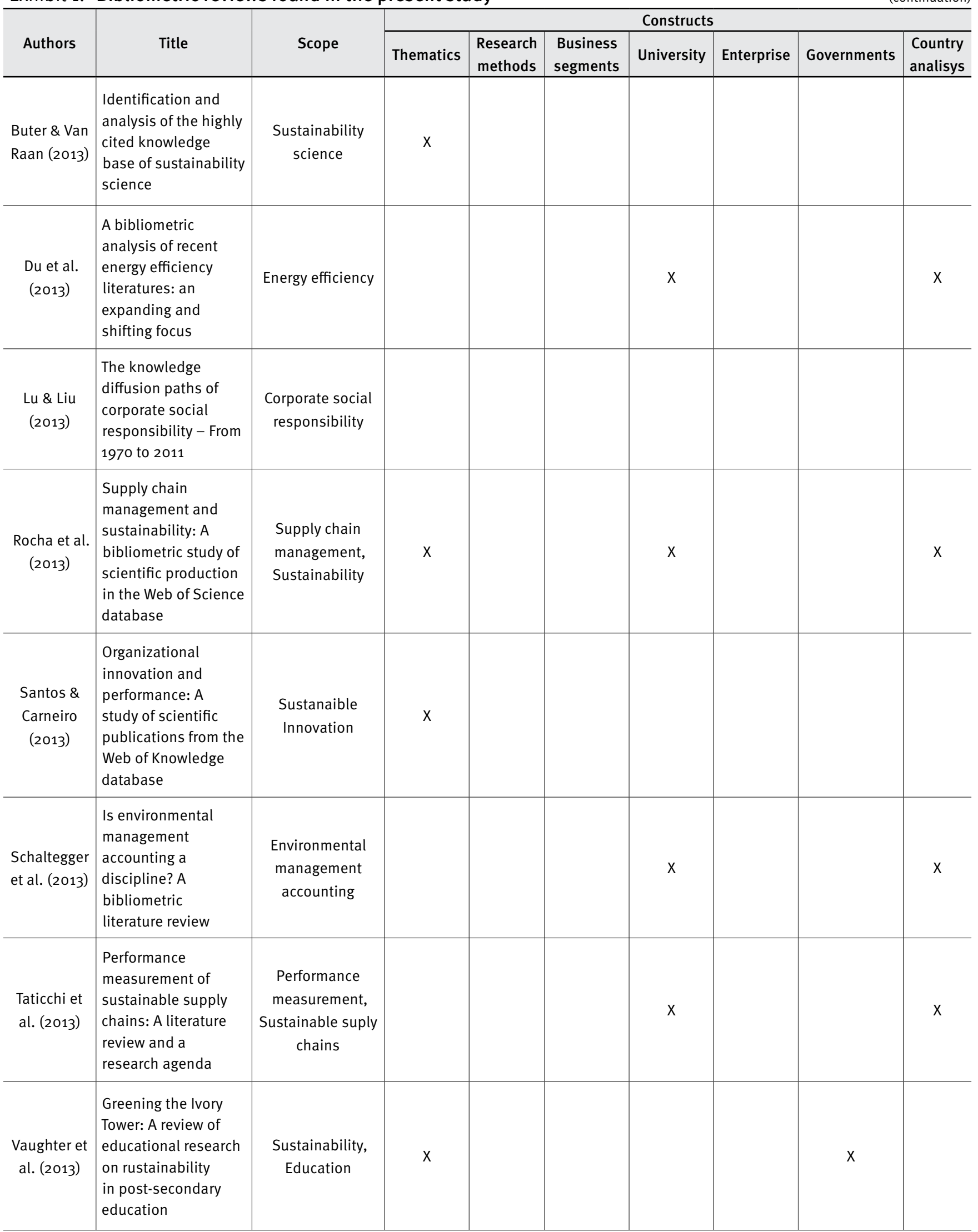




\section{Data analysis}

Following the data codification, the data extracted from the articles through lexical means were categorized: words were classified according to their meaning, using pairing and grouping (Bardin, 1986). This method enabled the identification of thematics, business segments, and research methods in the articles. Next, the authors' affiliations were identified. In addition, to identify the number of occurrences for each of these constructs, the networks were analyzed to establish the relationships among the constructs.

According to Pareto principles, $80 \%$ of the total is dependent on $20 \%$ of the whole, which is formally known as the $80 / 20$ rule. Thus, this rule was used for Brazilian universities.

A social network analysis examines the patterns of ties in a network of nodes and ties. In a social network, the nodes can be persons or firms that have activities in that both have the ability to make choices. Network metrics can be calculated at the node level and at the network level. Node-level metrics measure how an individual node is embedded in a network from that individual node's perspective. Network level metrics compute how the overall network ties are organized (Kim, Choi, Yan, \& Dooley, 2011).

In this analysis, the primary thematic (see Table 1) and Brazilian universities (see Table 3) were identified (Graph 1) to facilitate the analysis of social networks using UCINET-Draw in order to generate indicators and to substantiate graphics (Borgatti, 2002). However, when analyzing foreign universities, governments, and enterprises, $100 \%$ of cases were considered (see Table 3).

Next, the CP thematic was analyzed (219 articles), culminating in a single network showing the relationship among research methods and business segments. The main subjects of the papers were taken from the Principles of CP. Then, the networks were analyzed in order to establish the relationships among the most and least business segments investigated, the research methods, and subjects (see Table 2 ).

The networks of Brazilian and foreign universities, governments, and enterprises were analyzed based on 512 articles in two groups. The first group was composed of the following two steps, in which the total affiliations of authors of Brazilian universities were analyzed:

(i) The number of internal relationships (relationships among themselves) and the number of external relationships (publications with other universities, governments, and enterprises) are identified. For example, if an article has three authors, we analyzed whether they are affiliated with the same university (internal relationships; IR) or other universities, governments, and enterprises (external relationships; ER). Next, the data were recorded in the first column of Table 3.

(ii) Then, 32 universities from 15 relations were analyzed in detail to identify the most relevant relationships, allowing us to generate propositions about the research findings. The most important relationships were then recorded in the second column of Table 3. Note that in this network, repeated affiliations in the same article were excluded. In other words, we considered just one per item in order to evaluate the number of times each university, government, and enterprise appeared in a relationship.

The second group was composed of two steps, which analyzed the total affiliations of the authors in foreign universities, governments, and enterprises, considering all foreign affiliations, regardless of whether they had relationships with Brazilian entities:

(i) Overall, we measured the quantity of internal relationships (relationships among themselves) and the number of external relationships (publications performed with other universities, governments, and enterprises), as shown in the third column of Table 3.

(ii) The most relevant relationships (companies from four external relations, universities from three external relations, and all government affiliations) allowed us to generate propositions about the research findings, in addition to identifying the most important relationships. The results are shown in the fourth column of Table 3. This step repeated the procedure performed in step two of the first group.

In this study, the density was extracted from external relationships only. If a specific node or actor did not have an external relationship, then their density in the network is set to zero (Hanneman \& Riddle, 2005).

Then, we selected the strongest ties (cohesion) in each of the constructs studied. Here, we extracted the data from the most relevant relations among these constructs in order to create Table 3. According to De Nooy, Mrvar, and Batagelj (2005), analyzing the cohesion of a network enables the identification of the strongest ties, which represent the most important nodes of the relationships.

The bibliometric indicators of the social network analysis were as follows: (i) the degree of centrality (DC), which evaluates the number of ties that one element has in relation to others in 
the network (Wasserman \& Faust, 1994); if one element shows a larger number of connections, it is more centralized (Scott, 2000); (ii) the cohesion, which identifies the strongest ties relative to the researched universe (De Nooy et al., 2005); and (iii) the density, which evaluates the average force of all possible ties (Hanneman \& Riddle, 2005). According to Watts and Strogatz (1998), density is a measure of the intensity of interactions among network actors. Its measurement contributes to the formation of propositions about information that circulates through the network, which means it can be calculated for the network as a whole and for each of the programs.

\section{RESULTS AND ANALYSIS}

In this section, the thematics, research methods, and business segments of the JCP congress and their relationships are evaluated using social network indicators.

Graph 1 shows the main thematics of all articles published in $2007,2009,2011$, and 2013. The data indicate that the six most used thematics are cleaner production (219 publications), environmental management (76), sustainable development (47), energy (31), environmental education (29), and waste management (27).

\section{Graph 1. Thematics analysis of all articles published in 2007, 2009, 2011 and 2013 - IWACP}

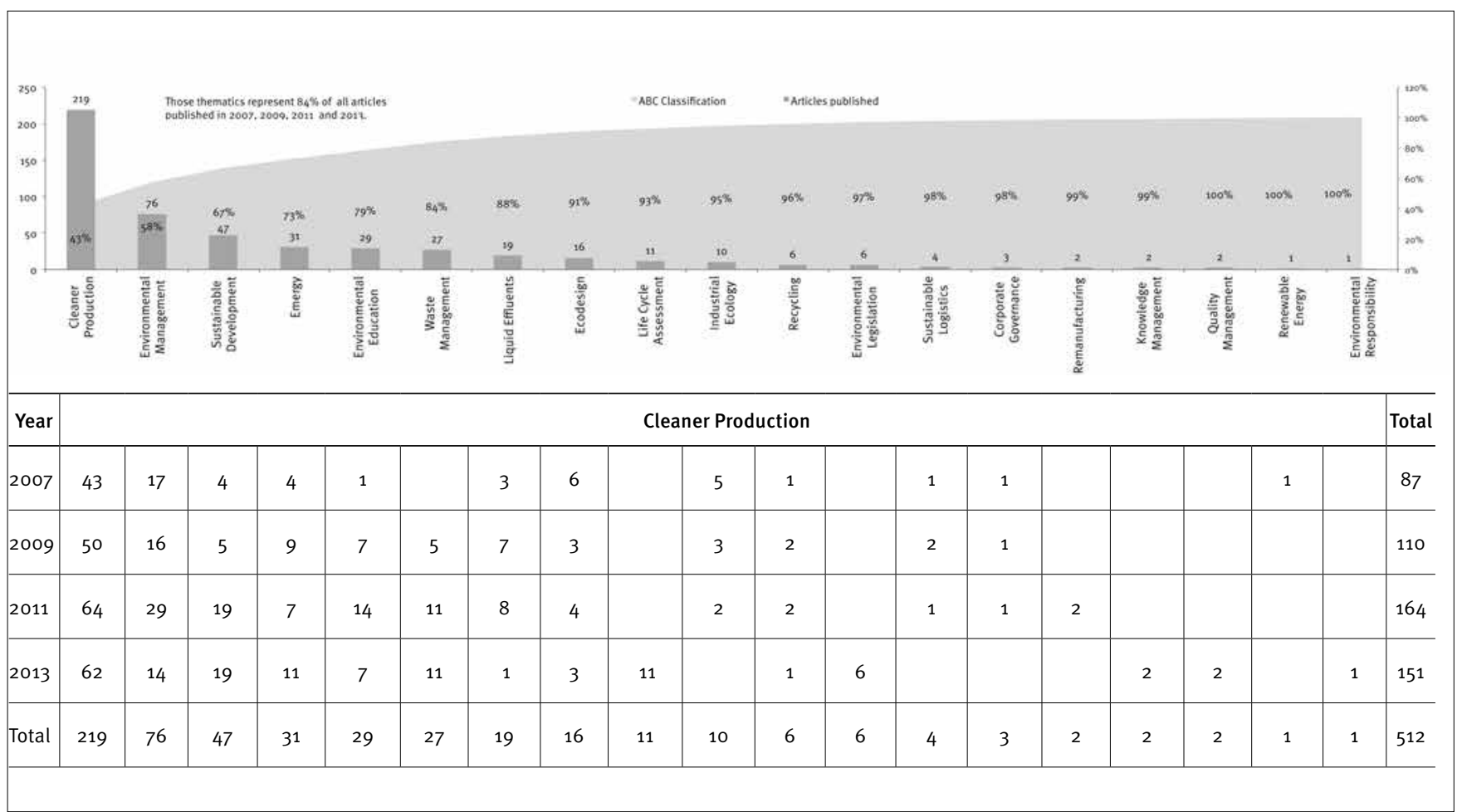

Table 1 measures the number of ties (T) and the degree of centrality (DC) in the relationships among thematics and business segments. The metal mechanics segment was the most studied business segment in the CP thematic. Agribusiness is the most studied segment in the sustainable development and energy thematic. The building sector is also widely studied in the energy thematic. With regard to environmental management, deals with more than one segment (several business segments) are more frequent than any other individual segment. The education segment is the most studied segment within environmental education, and landfills and agribusiness are the most frequent segments in waste management.
From Table 1, we can also see that case studies are the most used research method in the following thematics: $C P$, sustainable development, and environmental education. Case studies are also used frequently in the other three thematics, but other research methods are employed more often. Theoretical descriptive research is the most used research method for thematic environmental management and energy. Laboratory research is the most used research method for waste management. Other research methods, such as surveys, multiple cases, bibliometric research, and action research were rarely found in these six main thematics.

The average force of the ties indicates that in 2011 the CP thematic measured a larger density than it did in the other years (0.3516) and had a greater number of ties (64). 
Table 1. Relationship among thematics, research methods, and business segments

\begin{tabular}{|c|c|c|c|c|c|c|c|c|c|c|c|c|c|c|c|}
\hline \multicolumn{16}{|c|}{ Thematics } \\
\hline & \multicolumn{6}{|c|}{ Methods } & \multirow[b]{2}{*}{$\stackrel{n}{=}$} & \multirow[b]{2}{*}{ ப̆ } & \multicolumn{6}{|c|}{ Methods } & \multirow[b]{2}{*}{$\stackrel{\mathscr{g}}{=}$} \\
\hline $\begin{array}{l}\text { Business } \\
\text { segments }\end{array}$ & $\begin{array}{l}\vec{z} \\
\sum_{n} \\
0 \\
0 \\
\tilde{U}\end{array}$ & 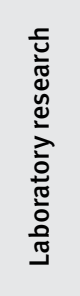 & 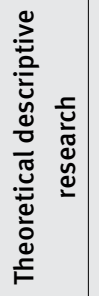 & 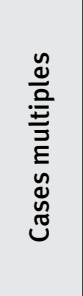 & 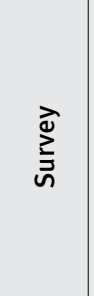 & 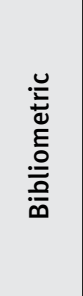 & & & 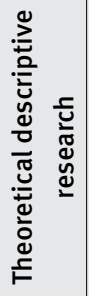 & 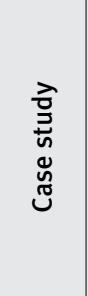 & 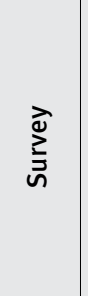 & 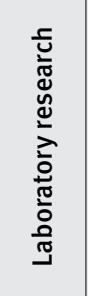 & 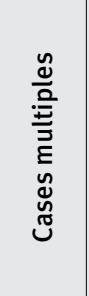 & 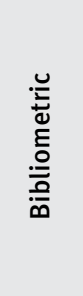 & \\
\hline Metal Mechanics & 8 & 4 & & 2 & 2 & & 16 & 0.327 & 1 & 2 & & & & & 3 \\
\hline Agribusiness & 6 & 7 & 2 & & & & 15 & 0.306 & & 1 & & 1 & & & 2 \\
\hline Plastics & 7 & 2 & & 1 & & & 10 & 0.204 & & & & & & & o \\
\hline Education & 4 & 4 & & & & & 8 & 0.163 & & 2 & & & & & 2 \\
\hline Fuel & 1 & 3 & 4 & & & & 8 & 0.163 & 1 & & & & & & 1 \\
\hline Furniture & 8 & 3 & & & & & 11 & 0.224 & & 1 & & & & & 1 \\
\hline Foods & 2 & 4 & 1 & & & & 7 & 0.143 & & 2 & & & & & 2 \\
\hline Automotive & 6 & 1 & & & & & 7 & 0.143 & 1 & 1 & & & & & 2 \\
\hline Electric & 4 & 4 & 2 & & & & 10 & 0.204 & & 4 & & & & & 4 \\
\hline Textile & 3 & 3 & & & & & 6 & 0.122 & & 2 & & & & & 2 \\
\hline Ceramic & 4 & 1 & & & & & 5 & 0.102 & & & & & & & o \\
\hline Several & & & & 4 & 1 & & 5 & 0.102 & & & 4 & & 2 & & 6 \\
\hline Electronics & 3 & 1 & & & & & 4 & 0.082 & 1 & & & & & & 1 \\
\hline Wooden artifacts & 1 & 1 & & 1 & & & 3 & 0.061 & & & & & & & 0 \\
\hline Others & 11 & 9 & 19 & 1 & o & 1 & 41 & 0.837 & 25 & 6 & 1 & o & 0 & 1 & 33 \\
\hline Ties total methods & 100 & 68 & 37 & 9 & 4 & 1 & 219 & ........... & 33 & 30 & 6 & 4 & 2 & 1 & 76 \\
\hline $\begin{array}{l}\text { DC Methodology } \\
\text { Individual Network } \\
\text { Thematics }\end{array}$ & 2.041 & 1.388 & 0.755 & 0.184 & 0.082 & 0.020 & & .......... & 0.150 & 0.136 & 0.027 & 0.018 & 0.009 & 0.005 & \\
\hline $\begin{array}{l}\text { DC Methodology } \\
\text { General Network } \\
\text { Thematics }\end{array}$ & 1.695 & 1.153 & 0.627 & 0.153 & 0.068 & 0.017 & 16,676 & .......... & 0.559 & 0.508 & 0.102 & 0.068 & 0.034 & 0.017 & 6,134 \\
\hline \multicolumn{8}{|c|}{ Cleaner Production } & $\ldots \ldots \ldots$ & \multicolumn{7}{|c|}{ Environmental Management } \\
\hline $\begin{array}{c}\text { Density Thematics } \\
\text { per year }\end{array}$ & \multicolumn{2}{|c|}{2007} & \multicolumn{2}{|c|}{2009} & 2011 & \multicolumn{2}{|c|}{2013} & .......... & \multicolumn{2}{|c|}{2007} & \multicolumn{2}{|c|}{2009} & 2011 & \multicolumn{2}{|c|}{2013} \\
\hline & \multicolumn{2}{|c|}{0.2756} & \multicolumn{2}{|c|}{0.3205} & 0.3516 & \multicolumn{2}{|c|}{0.3022} & ......... & 0.1 & & \multicolumn{2}{|c|}{0.1026} & 0.1593 & \multicolumn{2}{|c|}{0.0714} \\
\hline Ties per year & \multicolumn{2}{|c|}{43} & \multicolumn{2}{|c|}{50} & 64 & & 2 & $\ldots \ldots \ldots$. & 1 & & 1 & & 29 & & \\
\hline DC per year & & 33 & 8,3 & 33 & 7,692 & & 43 & $\ldots \ldots \ldots$ & 3,2 & & 2,6 & & 3,486 & & \\
\hline
\end{tabular}


Table 1. Relationship among thematics, research methods, and business segments

(continuation)

\begin{tabular}{|c|c|c|c|c|c|c|c|c|c|c|c|c|}
\hline \multicolumn{13}{|c|}{ Thematics } \\
\hline \multicolumn{6}{|c|}{ Sustainable Development } & & \multicolumn{6}{|c|}{ Emergy } \\
\hline \multicolumn{6}{|c|}{ Methods } & & \multicolumn{5}{|c|}{ Methods } & \multirow[b]{2}{*}{$\stackrel{\mathscr{\Phi}}{i}$} \\
\hline 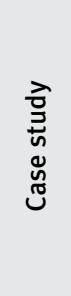 & 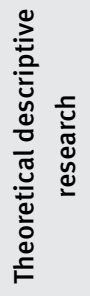 & 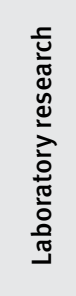 & 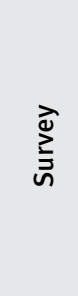 & 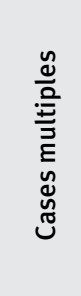 & 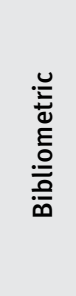 & $\stackrel{\mathscr{E}}{\oplus}$ & 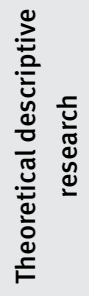 & 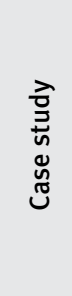 & 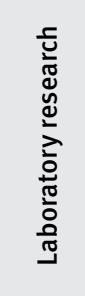 & 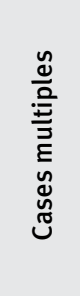 & 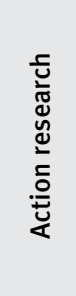 & \\
\hline & & & & & & 0 & & & & & & 0 \\
\hline 3 & 1 & 1 & 1 & & & 6 & 3 & 2 & 1 & & & 6 \\
\hline 2 & 1 & & 1 & & & 4 & 1 & & 3 & 1 & & 5 \\
\hline \multirow[t]{3}{*}{2} & & & & & & 2 & 1 & & 1 & & & 2 \\
\hline & & & & & & 0 & & & & & & 0 \\
\hline & & & & & & 0 & & & & & & 0 \\
\hline \multirow[t]{3}{*}{1} & & & & & & 1 & & 1 & 1 & 1 & & 3 \\
\hline & 2 & 1 & & & & 3 & & & & & & 0 \\
\hline & & & & & & 0 & & 1 & & & & 1 \\
\hline \multirow[t]{2}{*}{2} & 2 & & & & & 4 & & & & & & 0 \\
\hline & & & & & & 0 & & & & & 1 & 1 \\
\hline \multirow[t]{6}{*}{2} & 1 & & & & & 3 & 1 & 1 & & & & 2 \\
\hline & & & & & & 0 & & & & & & 0 \\
\hline & & & & & & 0 & & & & & & 0 \\
\hline & & & & 2 & & 2 & & & & & & 0 \\
\hline & & & & & & 0 & & & & & & 0 \\
\hline & & & & & & 0 & & & & & & 0 \\
\hline 1 & & & & & & 1 & & & & & & 0 \\
\hline \multirow[t]{2}{*}{1} & & & & & & 1 & & & & & & 0 \\
\hline & & & & & & 0 & & & & & & 0 \\
\hline \multirow[t]{4}{*}{1} & & & & & & 1 & & & & & & 0 \\
\hline & & & & & & 0 & & & & & & 0 \\
\hline & & & & & & 0 & & & & & & 0 \\
\hline & & & & & & 0 & & & & & & 0 \\
\hline 7 & 10 & 1 & 0 & 0 & 1 & 19 & 6 & 3 & 2 & 0 & 0 & 11 \\
\hline 22 & 17 & 3 & 2 & 2 & 1 & 47 & 12 & 8 & 8 & 2 & 1 & 30 \\
\hline 0.100 & 0.077 & 0.014 & 0.009 & 0.009 & 0.005 & & 0.055 & 0.036 & 0.036 & 0.009 & 0.005 & \\
\hline 0.373 & 0.288 & 0.051 & 0.034 & 0.034 & 0.017 & 3,793 & 0.203 & 0.136 & 0.136 & 0.034 & 0.017 & 2,502 \\
\hline
\end{tabular}

Sustainable Development

Emergy

\begin{tabular}{|c|c|c|c|c|c|c|c|}
\hline 2007 & 2009 & 2011 & 2013 & 2007 & 2009 & 2011 & 2013 \\
\hline 0.0256 & 0.0321 & 0.1044 & 0.0934 & 0.0256 & 0.0321 & 0.1044 & 0.0934 \\
\hline 4 & 5 & 19 & 19 & 4 & 9 & 7 & 11 \\
\hline 0.775 & 0.833 & 2,284 & 2,189 & 0.775 & 1,500 & 0.0385 & 1,267 \\
\hline
\end{tabular}

a Density (D); Ties (T); Degree Centrality (DC) 
Table 1. Relationship among thematics, research methods, and business segments

(continuation)

\begin{tabular}{|c|c|c|c|c|c|c|c|c|c|c|c|c|c|c|c|}
\hline \multicolumn{16}{|c|}{ Thematics } \\
\hline \multicolumn{8}{|c|}{ Environmental Education } & \multicolumn{8}{|c|}{ Waste Management } \\
\hline \multicolumn{7}{|c|}{ Methods } & & \multicolumn{5}{|c|}{ Methods } & \multirow[b]{2}{*}{$\stackrel{\mathscr{X}}{\stackrel{n}{\vdash}}$} & \multirow[b]{2}{*}{ 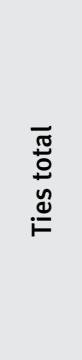 } & \multirow[b]{2}{*}{ ப } \\
\hline 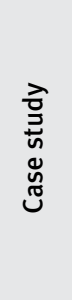 & 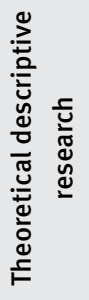 & 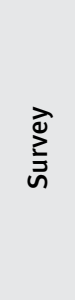 & 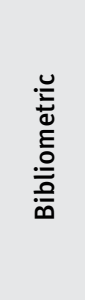 & 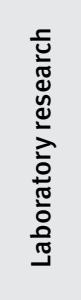 & 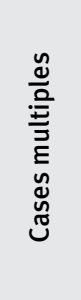 & 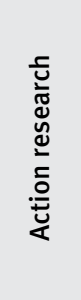 & $\stackrel{\mathscr{e}}{i=}$ & 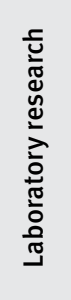 & 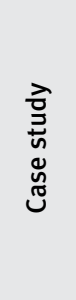 & 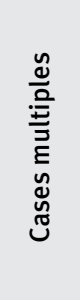 & 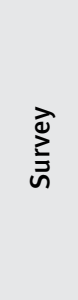 & 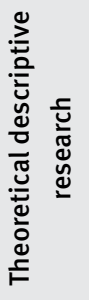 & & & \\
\hline & & & & & & & 0 & & & & & & 0 & 19 & 1,614 \\
\hline & & 1 & & & & & 1 & 2 & 2 & & & & 4 & 34 & 2,744 \\
\hline 1 & 1 & 1 & & & & & 3 & & & & & & 0 & 32 & 2,583 \\
\hline \multirow[t]{2}{*}{1} & & & & & & & 1 & & & & & & 0 & 23 & 2,341 \\
\hline & & & & & & & 0 & & & & & & 0 & 16 & 1,372 \\
\hline 1 & & & & & & & 1 & & & & & & 0 & 11 & 0.969 \\
\hline \multirow[t]{3}{*}{4} & 1 & 2 & & 1 & & 1 & 9 & & & & & & 0 & 23 & 1,776 \\
\hline & & & 1 & & & & 1 & & 1 & & & & 1 & 14 & 1,130 \\
\hline & & & & & & & 0 & & & & & & 0 & 13 & 1,049 \\
\hline \multirow[t]{15}{*}{2} & & & & & & & 2 & & 1 & 1 & & & 2 & 17 & 1,695 \\
\hline & 1 & & & & & & 1 & & & & 1 & & 1 & 12 & 1,211 \\
\hline & & & & & & & 0 & 1 & & & & & 1 & 20 & 1,614 \\
\hline & & & & & & & 0 & 1 & & & & & 1 & 9 & 0.807 \\
\hline & & & & & & & 0 & & & & & & 0 & 5 & 0.404 \\
\hline & & 1 & & & & & 1 & & & 1 & 1 & & 2 & 16 & 1,291 \\
\hline & & & & & & & 0 & & & & & 1 & 1 & 6 & 0.484 \\
\hline & & & & & & & 0 & & & & & & 0 & 4 & 0.323 \\
\hline & & & & & & & 0 & & & & & & 0 & 5 & 0.404 \\
\hline & & & & & & & 0 & 3 & 1 & & & & 4 & 8 & 0.646 \\
\hline & & & & & & & 0 & & & & & & 0 & 4 & 0.323 \\
\hline & & & & & & & 0 & & & & & & 0 & 6 & 0.565 \\
\hline & & & & & & & 0 & & & & & & 0 & 3 & 0.242 \\
\hline & & & & & & & 0 & & & & & & 0 & 3 & 0.323 \\
\hline & & & & & & & 0 & & & & & & 0 & 3 & 0.242 \\
\hline 3 & 4 & 0 & 1 & 0 & 1 & 0 & 9 & 2 & 4 & 1 & 1 & 2 & 8 & 103 & ........... \\
\hline 12 & 7 & 5 & 2 & 1 & 1 & 1 & 29 & 9 & 9 & 3 & 3 & 3 & 27 & .......... & .......... \\
\hline 0.055 & 0.032 & 0.023 & 0.009 & 0.005 & 0.005 & 0.005 & & 0.041 & 0.041 & 0.014 & 0.014 & 0.014 & 0.123 & .......... & .......... \\
\hline 0.203 & 0.119 & 0.085 & 0.034 & 0.017 & 0.017 & 0.017 & 2,341 & 0.153 & 0.153 & 0.051 & 0.051 & 0.051 & 2,179 & .......... & ......... \\
\hline
\end{tabular}

Environmental Education

Waste Management

\begin{tabular}{|c|c|c|c|c|c|c|c|c|}
\hline 2007 & 2009 & 2011 & 2013 & 2008 & 2009 & 2011 & 2013 & .......... \\
\hline 0.0256 & 0.0321 & 0.1044 & 0.0934 & Null & 0.0321 & 0.0604 & 0.0549 & .......... \\
\hline 1 & 7 & 14 & 7 & Null & 5 & 11 & 11 & .......... \\
\hline 0.194 & 1,167 & 0.0769 & 0.806 & Null & 0.833 & 1,322 & 1,267 & …......... \\
\hline
\end{tabular}

a Density (D); Ties (T); Degree Centrality (DC) 
With regard to the goals of this research, the focus henceforth is on the CP thematics. From Table 1, specifically for CP thematics, we developed a single network showing the relationships among research methods and business segments. Graph. 2 shows that the case study method was the most used research method, demonstrating greater cohesion (100 ties), which represents the strongest ties in relation to the other research methods. Laboratory research and theoretical descriptive research are also common. Other research methods, such as multiple cases, surveys, action research, and bibliometrics, are scarce.

\section{Graph 2. Relationships among business segments and research methods for CP thematics.}

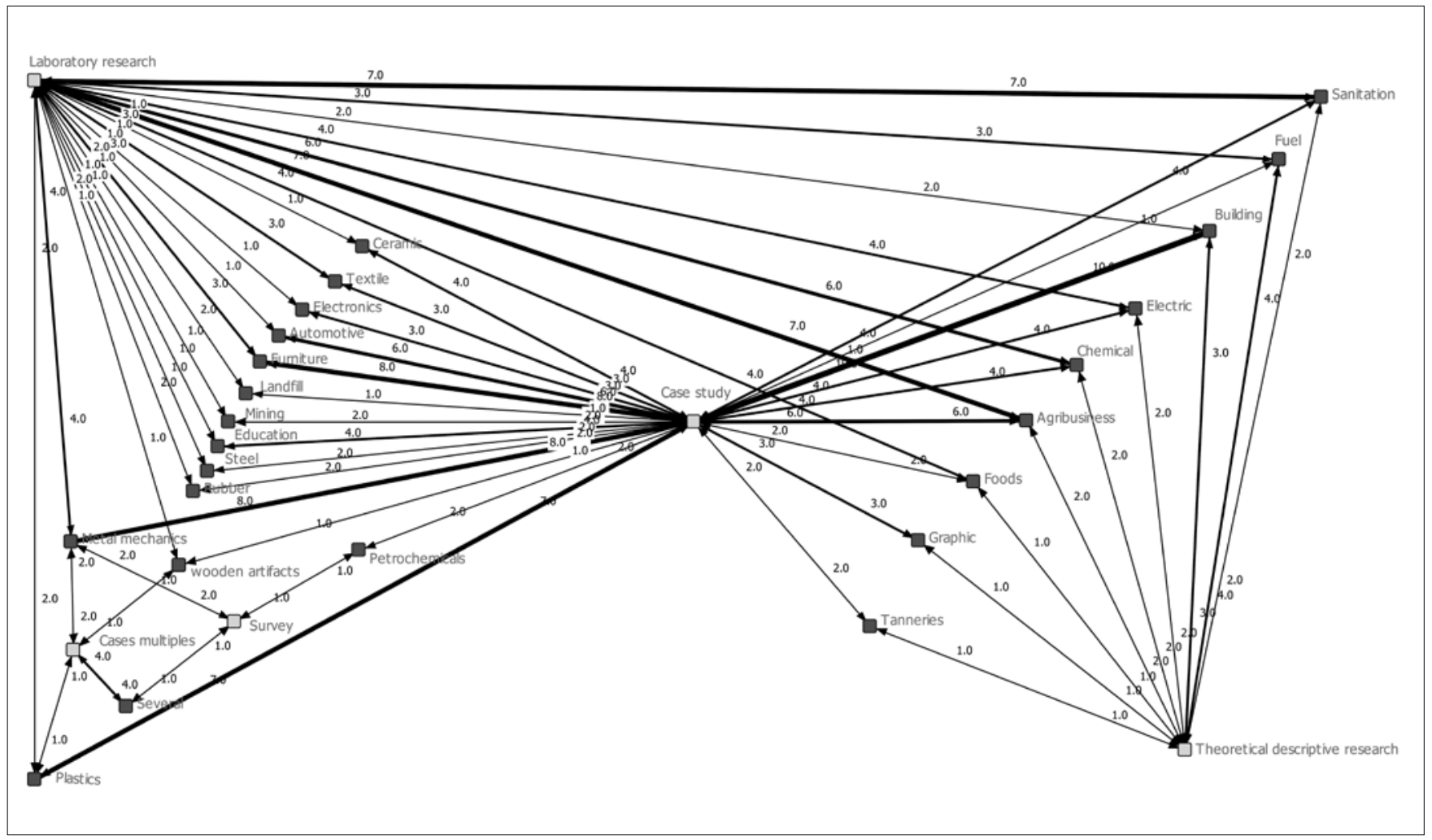

Table 2 (and Graph 3 and 4, respectively) show the most studied and least studied business segments, the relationship among research methods, and the main subjects addressed in the papers. These main subjects were taken from the Principles of CP (Glavič \& Lukman, 2007; Giannetti, Ogura, Bonilla, \& Almeida, 2012; García, Pongrácza, Phillips, \& Keiski, 2013): (1) the reduction and nongeneration of emissions and resources; (2) economic and environmental benefits; (3) efficiency of the use of raw materials; (4) efficiency of the use of water; (5) efficiency of the use of energy; (6) recycling/reuse of wastes and emissions; and (7) occupational health benefits.

\section{Table 2. The most and least studied business segments, and the relationships among research methods and subjects}

\begin{tabular}{l|l|l|l|c|c|l}
\hline $\begin{array}{l}\text { Business } \\
\text { segments }\end{array}$ & T & DC & Research methods & T & DC & Subjects \\
\hline \multirow{2}{*}{ Metal Mechanics } & \multirow{2}{*}{0.696} & Case study & 8 & 0.348 & (8) Economic and environmental benefits \\
\cline { 3 - 7 } & & Laboratory research & 4 & 0.174 & (4) Reduction and non-generation of emissions and resource \\
\cline { 3 - 7 } & & Cases multiples & 2 & 0.087 & $\begin{array}{l}\text { (2) Reduction and non-generation of emissions and } \\
\text { resource }\end{array}$ \\
\cline { 3 - 7 } & & Survey & 2 & 0.087 & $\begin{array}{l}\text { (1) Efficiency of the use of raw materials } \\
\text { (1) Occupational health benefits }\end{array}$ \\
\cline { 3 - 6 } & & $\begin{array}{l}\text { Theoretical descriptive research, } \\
\text { action research and bibliometrics }\end{array}$ & 0 & 0 & Not found \\
\hline
\end{tabular}


Table 2. The most and least studied business segments, and the relationships among research methods and subjects (continuation)

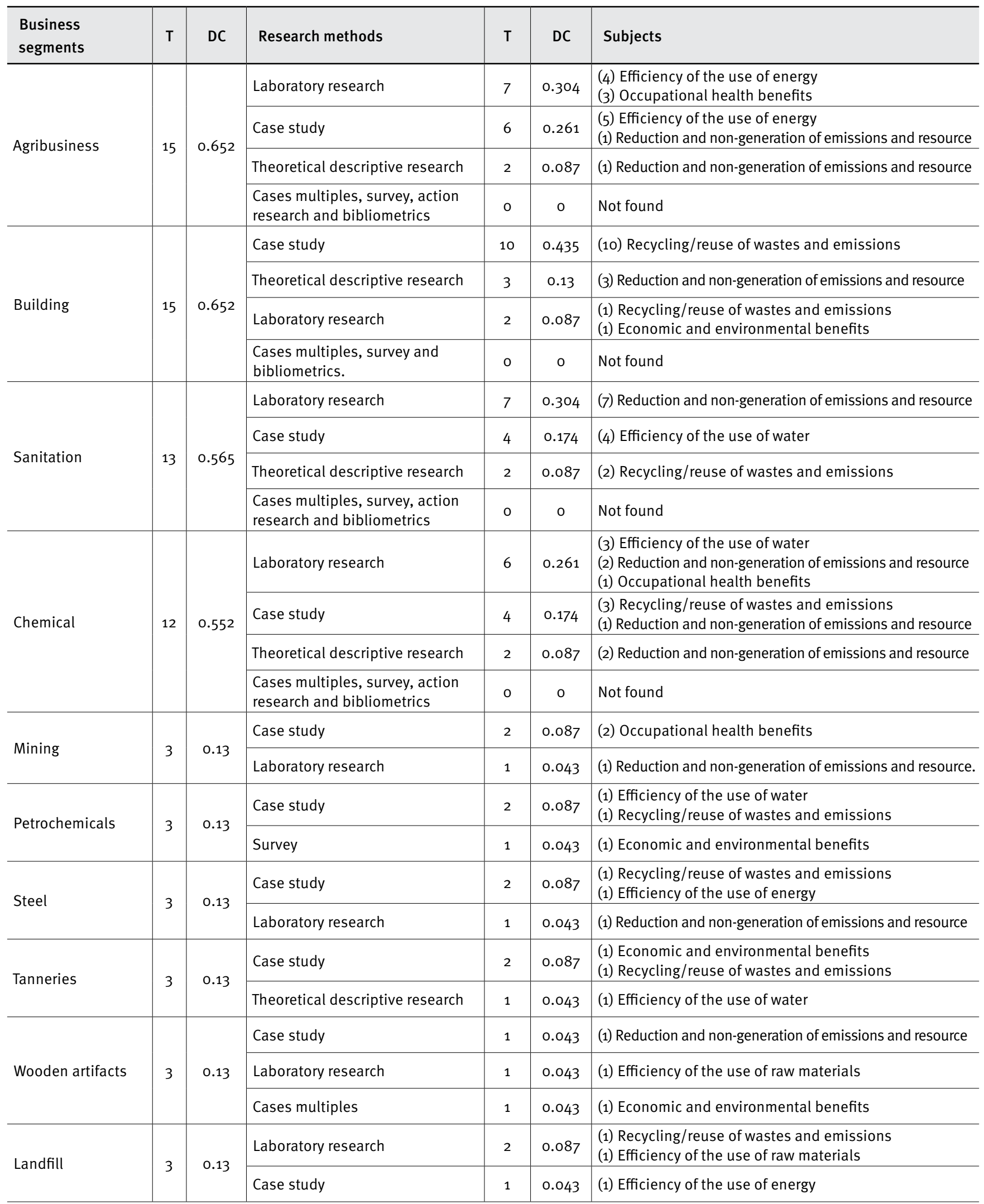


Graph 3 shows that the subject most studied was recycling/reuse of wastes and emissions (RRWE; 13 ties) in the building segment (10) using case studies. This was followed by the reduction and non-generation of emissions and resources (RNGER; 13 ties) in the sanitation segment (7) using laboratory research. Then, the subject efficiency of the use of raw materials (EURM; 1 tie) and occupational health benefits (OHB; 1 tie) in metal mechanics using surveys were the least surveyed.

\section{Graph 3. Relationships among research methods and CP subjects for the most studied business segments}

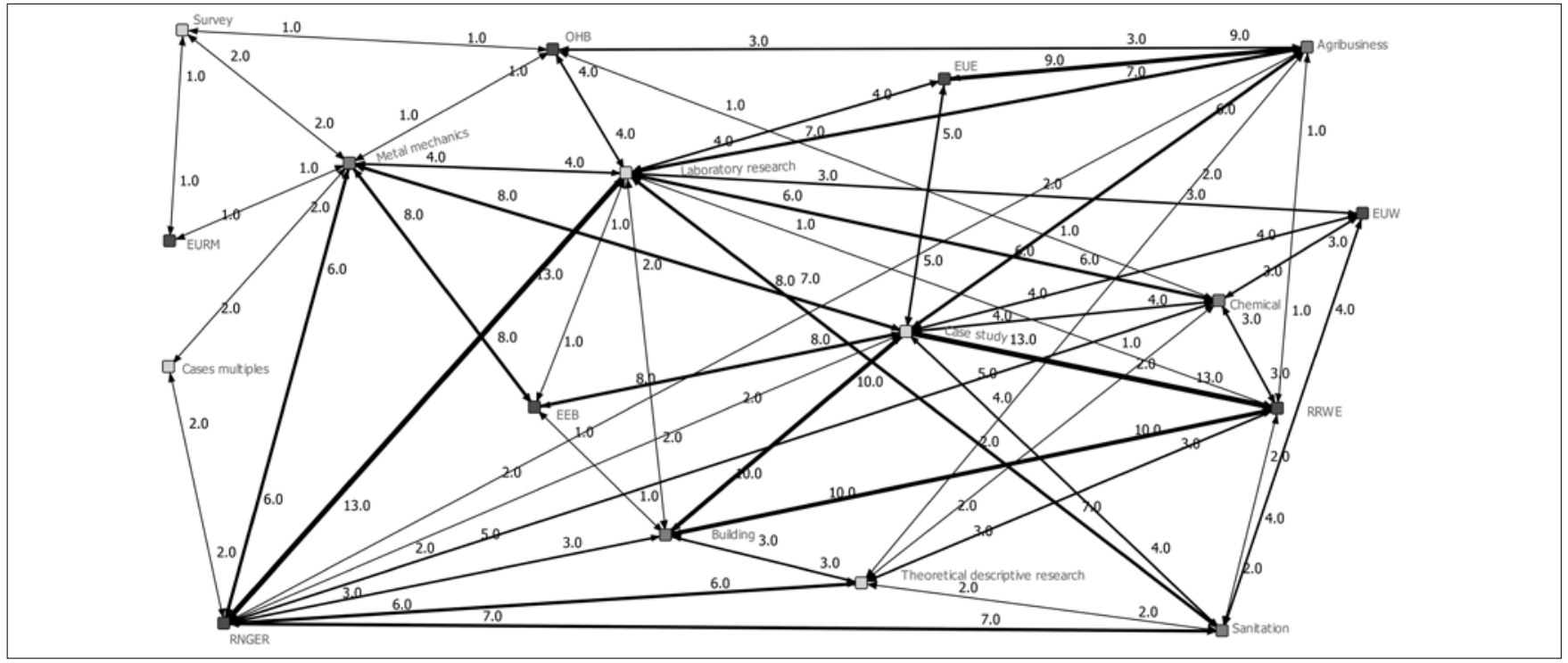

Legend: Reduction and non-generation of emissions and resource (RNGER); Economic and environmental benefits (EEB); Efficiency of the use of raw materials (EURM); Efficiency of the use of water (EUW); Efficiency of the use of energy (EUE); Recycling/reuse of wastes and emissions (RRWE) and Occupational health benefits (OHB)

Graph 4 shows that in the less studied business segments, case studies (10 ties) and laboratory research (5 ties) on recycling/ reuse of wastes and emissions prevails (RRWE; 4 ties, and case studies 3).

\section{Graph 4. Relationships among research methods and CP subjects for the least studied business segments}

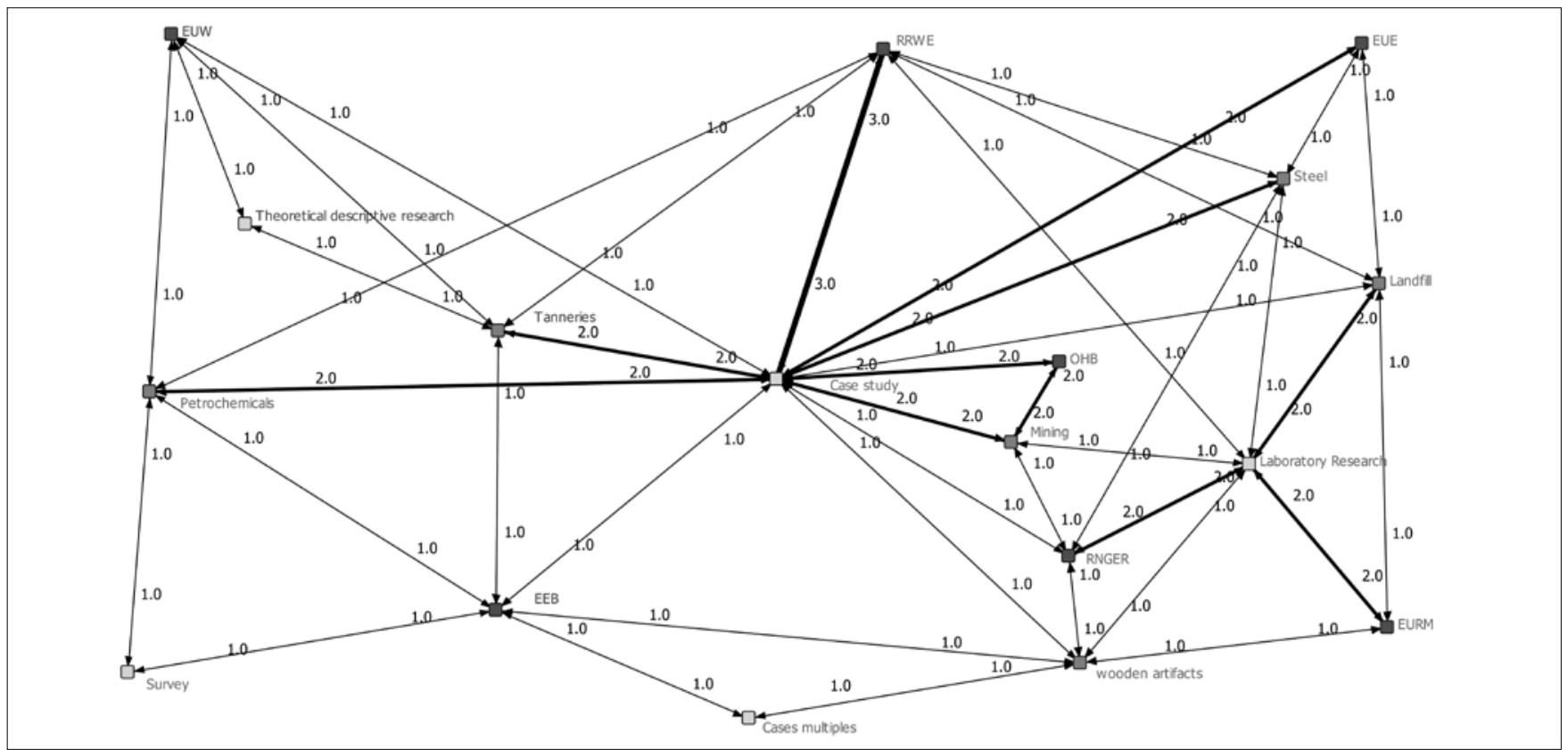

Legend: Reduction and non-generation of emissions and resource (RNGER); Economic and environmental benefits (EEB); Efficiency of the use of raw materials (EURM); Efficiency of the use of water (EUW); Efficiency of the use of energy (EUE); Recycling/reuse of wastes and emissions (RRWE) and Occupational health benefits (OHB) 
The relationships among the universities, enterprises, and governments of the 512 papers of the JCP congress will be evaluated using social network indicators.

The participation of Brazilian and foreign universities, enterprises, and governments was evaluated in terms of absolute values and percentages per year, as shown in Graph 5. This figure shows that the participation of these bodies is superior to the participation of foreign universities, enterprises, and governments. The figure also shows that the participation of universities is much higher than the participation of the government and enterprises. Graph 5 shows that the relative participation of international universities increased during the last two events, and that the participation of international audiences has increased. The participation of international enterprises and governments is scarce and remains fairly stable during the four years under study.

\section{Graph 5. Participation of the universities, enterprises and government in the IWACP}

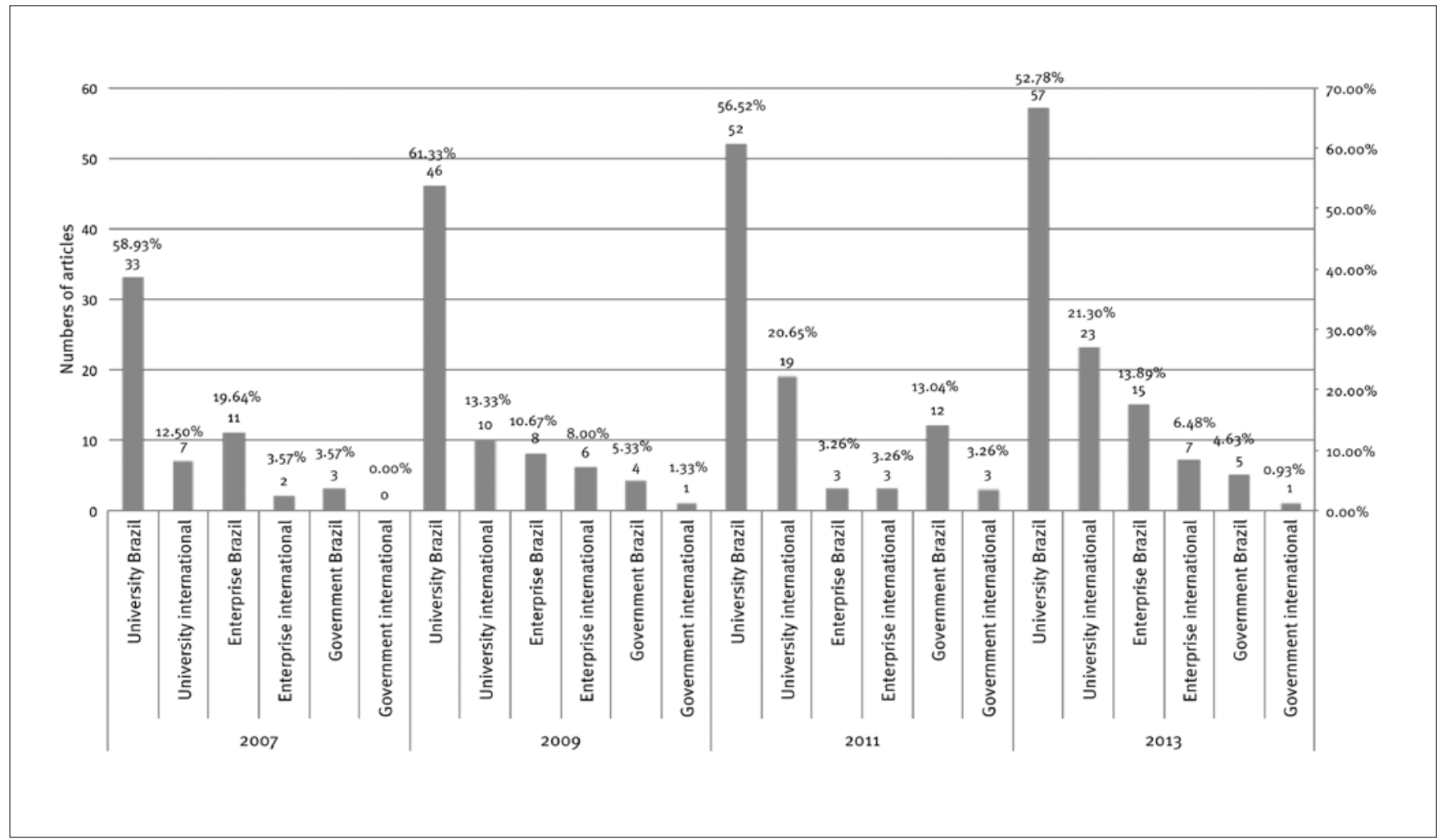

From the graphs in Graph 6, we conclude that the relations with the most cohesion are U-UNIP/BRAZIL/SP, U-UNICAMP/ BRAZIL/SP, U-USP/BRAZIL/SP and U-IFSULDEMINAS/BRAZIL/ $M G$, with four ties, and DC of 0.106 shows the low participation of governments and enterprises. According to De Nooy et al. (2005), an analysis of the cohesion of a network enables the identification of the strongest ties, which represent the most important nodes of the relationships.

The results indicate low participation in $\mathrm{CP}$ research, because of the absence of coordination and organization for the participation of Brazilian government agents. Here, there were just five participations (G-CETESB/BRAZIL/SP, G-IPEN/BRAZIL/ SP, G-IPT/BRAZIL/SP, G-INPA/BRAZIL/AM, G-IDR/BRAZIL/PR), representing $5 \%$ of the actors in this network.
It was found that 18 enterprises conducted joint studies with universities and governments on sustainability practices in $C P$. The enterprise that performed the most studies in cooperation with universities was the E-SEBRAE/BRAZIL/AM, with six ties, followed by E-TECNOAMBI/BRAZIL/RS, and E-SENAI/BRAZIL/RS, which had three external relationships.

Another aspect identified in the analysis of the networks, as shown in Graph 6, is isolated relationships. It is also important to clarify that the actors that are without ties only published internally, as is the case for U-UFTPR/BRAZIL/PR and U-UNISC/BRAZIL/RS. A proposition for this finding is that these universities are situated in regions with the most conservative cultures of Brazil, as is the case for the State of Paraná and Rio Grande do Sul. However, in the study by Yanhua et al. (2011), one of the causes of isolation was an idiom-related problem. 
Graph 6. Relationships among Brazilian universities with the largest numbers of ties with enterprises and governments

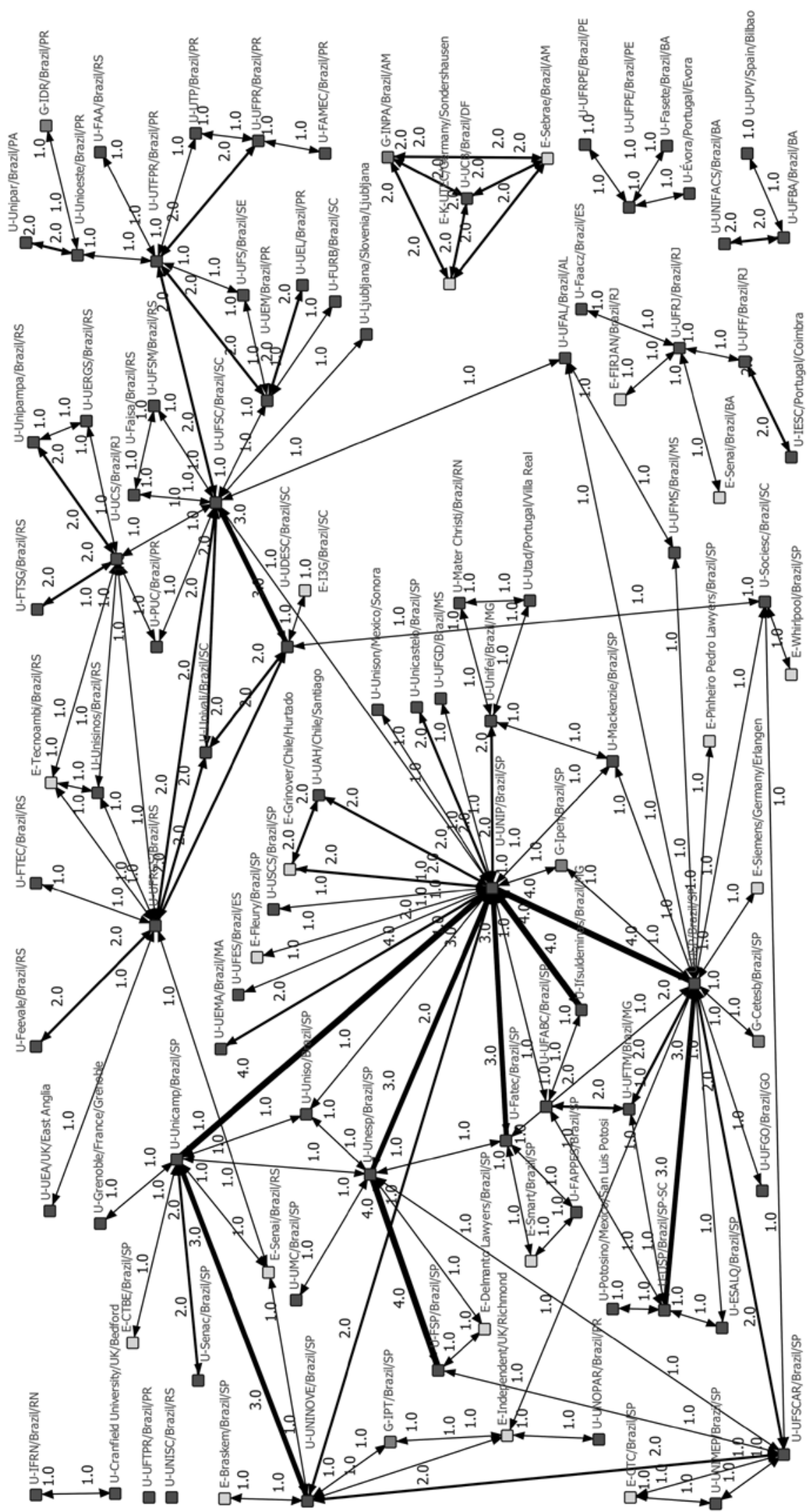


Graph 7 shows that universities are related independently of geographic location, for example: (i) U-UAH/CHILE/SANTIAGO (2 ties, DC: 0.114) for U-UNIP/BRAZIL/SP and E-GRINOVER/CHILE/ HURTADO; (ii) U-NTNU/NORWAY/TRONDTHEIM, related twice with the U-UFRN/BRAZIL/RN (1 tie, DC: 0.057) with U-UNOPAR/BRAZIL/PR and E-INDEPENDENT/UK/RICHMOND. However, Yarime et al. (2010) states that collaboration networks are formed among countries that are geographically close, which contradicts the above findings.

Another result is the participation of three international government agencies that did not have relationships.

The main enterprises are consulting firms and service providers, which can relate to other universities and the government at the same time, for example, E-INDEPENDENT/ UK/RICHMOND. According to Radosevic (2008), enterprises that lead in innovation promote more studies.

Table 3 was developed by selecting the strongest ties under each of the constructs studied. This table shows universities, enterprises, and governments and the most relevant relations among these constructs. Some findings arise from this table are as follows:

- Brazilian institutions (universities, government, and enterprises) present a low level of relationships with foreign institutions.

- Brazilian universities show far more external relationships than Brazilian enterprises do. This fact is the opposite of what happens overseas, where enterprises present more external relationships than universities do.

- Many universities, governments, and enterprises show zero external relationships. This represents a gap and an opportunity for performing joint studies among these constructs.

\section{DISCUSSION}

The most researched $\mathrm{CP}$ topics in Brazil are environmental management, sustainable development, energy, environmental education, and waste management. These issues have deployment synergy and so are the most used in cases. For instance, a Brazilian organization that decides to implement CP needs to train those involved in environmental education, especially if they adopt an environmental management system focused on minimizing energy, water, and waste management. Therefore, the implementation of these thematics enhances sustainable development in Brazil. Karatzoglou (2013) confirm this result, and concludes that the adoption of CP principles in production systems is an excellent strategy for sustainable development.
On the other hand, several important issues closely related to $\mathrm{CP}$ have received little attention, for instance, renewable energy and environmental responsibility. To increase research on these issues, the Brazilian government could (a) invest in research among universities, enterprises, and government, (b) reduce taxes for companies that use renewable energy and that are environmentally responsible, and (c) establish programs to promote environmental awareness among companies and people. The study on China by Chang et al. (2015) concluded that the government should establish financial assistance or provide sources of financing and investment in technical training to enhance the adoption of CP practices. Therefore, in developing countries such as Brazil and China, the participation of government agencies, enterprises, and universities is important to enhancing CP in industries. The application of research and business practices with renewable energy and environmental responsibility among Brazilian industries may also improve their competitiveness and enable them to commit to sustainable development.

Additionally, $\mathrm{CP}$ research found that intensity-related $\mathrm{CP}$ principles are as the reduction and non-generation of emissions and resources, recycling/reuse of waste and emissions, and economic and environmental benefits are used more often. This is because the Política Nacional de Resíduos Sólidos (PNRS, 2010) was published in 2010, which advocated practical actions related to the management of industrial solid waste, thus motivating research. Furthermore, Brazil is a developing country. Thus, researchers seek to associate economic gains with environmental benefits achieved by adopting $\mathrm{CP}$ as a way to boost its implementation. Moreover, the principles of $C P$ least studied are associated with the use of raw materials. This is because the majority of companies in Brazil do not use CP technologies. In order to change this situation, a simultaneous effort among companies, the government, and universities is necessary to promote such effort. Thus, the possible consequences are as follows: (a) reducing the consumption of natural resources; and (b) contributing for companies to reduce their costs in the medium/ long term. In this context, the main barriers are a lack of CP law in Brazil to promote environmental responsibility or the use of renewable energy, a lack of long-range vision by entrepreneurs who invest in Brazilian companies, and a lack of technology and specialized people able to work with renewable energy and promote the efficient use of raw materials. For instance, in China, the CP law was promulgated in $\mathbf{2 0 0 2}$ to facilitate the development CP. This law was altered in 2012 to further promote CP, as indicated by Chang et al. (2015). Vieira and Amaral (2016) emphasize that CP laws would enhance educational discourse.

Another relevant aspect is that the most used research methods are case studies (many of which are exploratory), theoretical descriptive research, and laboratory research, surveys, and bibliometric analyses. 
Other practical methods (multiple case, surveys, and action research) are scarce, and should be developed to spread the subject and promote practical application. To promote the use of this type of research, it is necessary to develop partnerships between universities and companies. This is rarely found in Brazil, and needs to be stimulated. In addition, the results should be presented in a more detailed way. A possible consequence of changing the observed situation is that the development of applied research tends to increase companies' interest in CP technologies and methods. It is expected that this will lead to a virtuous cycle between research generation and the application of CP methods in Brazil, according to Leonidou and Leonidou (2011). The method of analysis consists of evaluating whether the studies showed greater consistency in their results. Vieira and Amaral (2016) analyzed research on why CP is not widely adopted, and found that there is a need to improve $\mathrm{CP}$ application methods, which is related to the innovation of new methodological procedures.

However, there are barriers to using action research and other research methods in the production system that negatively impact the adoption of CP in Brazilian industries. For instance, some companies are reluctant to share information, while others do not want to share negative results on the application of $\mathrm{CP}$ methods or environmental or economical results. Furthermore, resources from the Brazilian government are restricted, and there are few researchers exclusively dedicated to research. Chang et al. (2015) confirmed that in China, the acceptance by companies of CP provide opportunities to improve $\mathrm{CP}$ technical training, especially considering the motivation of researchers.

Some of the most studied business segments within CP are metal mechanics, building, and agribusiness. This is because several companies in these sectors are located in Brazil. These business segments and their intrinsic characteristics are more familiar with CP. On the other hand, some of the least studied segments are landfills, petrochemicals, steel, mining, tanneries, and wooden artifacts. Thus, it is necessary to promote CP in these business segments. Karatzoglou (2013) states that sustainable development in countries may be enhanced with the implementation of $C P$ in all business segments. For instance, Deng et al. (2015) indicate that opportunities exist to reduce the occupational risk in the tannery sector by minimizing carbon dioxide generation as a CP strategy. Rocha et al. (2012b) added that the analysis of segments shows the scope and acceptability of sustainable development in a country.

Changing this situation would spread the use of $\mathrm{CP}$ to sectors that have not been studied and can lead companies in these business segments to implement such technologies and methods. However, in Brazil, barriers that hinder the implementation of $\mathrm{CP}$ need to be reduced. For instance, the dissemination of funds granted by the Brazilian government in the case of projects related to the adoption of technological innovations in companies needs to improve. The
Brazilian government provides financial resources for projects through Fundação de Amparo à Pesquisa do Estado de São Paulo (FAPESP). This finding was confirmed by Chang et al. (2015), who state the need to improve communication among various business sectors as a way to increase research projects using funding. Other barriers preventing $\mathrm{CP}$ include entrepreneurs who are not sure about the benefits of adopting CP technologies and methods, and a lack of technology and specialized people able to work with CP. To overcome these barriers, communication in sectors on existing is required to encourage the acceptance by entrepreneurs and to improve the technical capacity of those involved. This result is common in developing countries, as pointed out by Chang et al. (2015).

The participation of Brazilian universities, enterprises, and the government is superior to the participation of foreign universities, enterprises, and governments. However, the relative participation of international universities has increased, as has the participation of foreign government agencies. However, $75 \%$ conducted isolated studies. This finding was indicated by RomoFernández et al. (2012), referring to the growth in government participation in studies. In order to improve this situation, it is necessary to increase external partnerships to boost foreign participation in events, which requires publishing papers that show the economic and social benefits of implementing $C P$. According to Radosevic (2008) and Romo-Fernández et al. (2012), the government needs to organize the relationships among the government, universities, and enterprises. The studies by Wright and Pullen (2007), Radosevic (2008), Yarime et al. (2010), Kneipp et al. (2011), Chai and Xiao (2012), Rosa et al. (2012a), Taticchi et al. (2013), Rocha et al. (2013), Avila et al. (2013), and Du et al. (2013) indicate that large investments are necessary to boost research in universities.

The types of businesses that show greater participation are consulting companies and service providers. In order to change this situation, the Brazilian government should develop joint research between universities and companies. An example of such an effort is the Brazilian Plano de Ação para Produção e Consumo Sustentáveis - 2011-2014 (PPCS), which aims to organize the relationships among the government, universities, and enterprises. This result is corroborated by Radosevic (2008), who states that success in the process of innovation depends upon joint action between universities and enterprises. Chang et al. (2015) agree on improving the system of communication between companies and universities to exchange experiences. For instance, in reviewing the literature, Riaz et al. (2015) show that most research on the use of $\mathrm{CP}$ in the manufacture of methanol is the result of interaction between companies and universities.

However, the results indicate that 10 enterprises did not develop studies with universities and government organizations, and 
did not share the results in partnership with universities, primarily the E-RHODIA/BRAZIL/SP, with three internal relationships. This finding agrees with those of Boks et al. (2001), who state that when enterprises publish, they do so in an isolated manner. In this context, it is suggested that enterprises can become more tractable for studies from universities with the support of government agencies, making it possible to integrate efforts in developing more detailed studies in the area of sustainability in production. Another relevant aspect of this analysis, identified in the study by Brito and Berardi (2010), is that enterprises are influenced by the government and society to create and implement new sustainability practices in the production system. According to Vieira and Amaral (2016), it is necessary to promote the dissemination of knowledge about CP to stakeholders, including businessmen, academics, government, and society.

There are few relationships/partnerships among Brazilian and foreign universities, enterprises, and government. In order to improve this situation, it is necessary to create partnerships to generate research and practical applications among these bodies, according Vieira and Amaral (2016). China, Italy, and Portugal, for example, have published various studies on CP. It is possible that a closer relationship with these countries would allow for the generation of more international submissions. This finding indicates that universities are related, regardless of their geographic location. However, Yarime et al. (2010) state that networks of collaboration are formed among countries that are geographically close, which contradicts the above findings.

The lack of relationships/partnerships among universities, enterprises, and government is valid for Brazilian and foreign institutions. Many universities, governments, and enterprises show no external relationships. This represents a gap and an opportunity for performing joint studies among these constructs. To improve this situation, partnerships that generate research and practical applications among universities, enterprises, and government are required. This is in line with the findings of Radosevic (2008) and Romo-Fernández et al. (2012), who claims the need of such relationships, along with government support. Some Brazilian universities are already developing partnerships in masters and doctoral programs. The analysis performed in this study supports the inquiries of Boks et al. (2001) and Radosevic (2008) in terms of the joint participation of universities, enterprises, and governments being important for the development of emerging thematics in sustainability.

There are a number of possible consequences of changing the observed situation. Government support and the establishment of partnerships could increase the participation of international institutions in the event, which contributes to better quality articles and an increase in the level of the event. Partnership among universities and companies and the government tend to generate applied research, which increase the enthusiasm of companies to implement CP technologies and methods. It is expected that this will lead to a virtuous cycle between research generation and the application of CP methods in Brazil, with the population becoming conscious of the importance of sustainable consumption, leading to companies implementing CP. Furthermore, Brazil can learn from foreign experiences. This finding is consistent with Chang et al. (2015) and Vieira and Amaral (2016) on the formation of networks of relationships among the government, businesses, universities, and the community for the internationalization of CP research.

On the other hand, barriers to establishing partnerships among universities, enterprises, and the government also exist between Brazilian and foreign institutions: scarce financial resources, low levels of internationalization of Brazilian universities on CP subjects, and a lack of laws in Brazil that incentivize CP. This result is consistent with Chen, Tang, and Feldmann (2015), who refer to developing or underdeveloped countries who are looking for ways to improve their economies. For example, China understands the need to adopt $\mathrm{CP}$ as a means of promoting sustainable development, but is still at the trend level, according to Chang et al. (2015). Brazil is currently in a political and economic crisis and focusing on ways to maintain or improve gross domestic production and, thus, has begun discussing laws of development, starting with the PPCS. Chang et al. (2015) focused on China, but the asymmetry with the Brazilian scenario suggests that the effectiveness of $C P$ requires improving the institutional system focused on laws for implementing CP in industries, and recognizing opportunities to integrate $\mathrm{CP}$ with other environmental management schemes, for instance, emission reduction and energy conservation, total emission control, environmental impact assessments, and emission permits.

This study expands the debate and discussions in this research area, which we believe to be its main contribution. The specific conference targeted to promote $\mathrm{CP}$ themes supported by the Journal of Cleaner Production creates important integration among universities, businesses, and the government. When researchers receive grants and incentives from the government or companies, they can develop improved techniques from which everyone will benefit. When the most effective $\mathrm{CP}$ procedures are implemented in several companies, research can establish a pattern. Moreover, successful cases and articles can spread the practices used in companies. The government can also benefit from this improvement, owing to the fact that this idea helps them to control the procedures applied in the companies and reduces the costs and investment of the government. For instance, the costs of water treatment become cheaper when CP concepts are properly applied. 
Graph 7. Network of the foreign relationships among universities, enterprises, and government

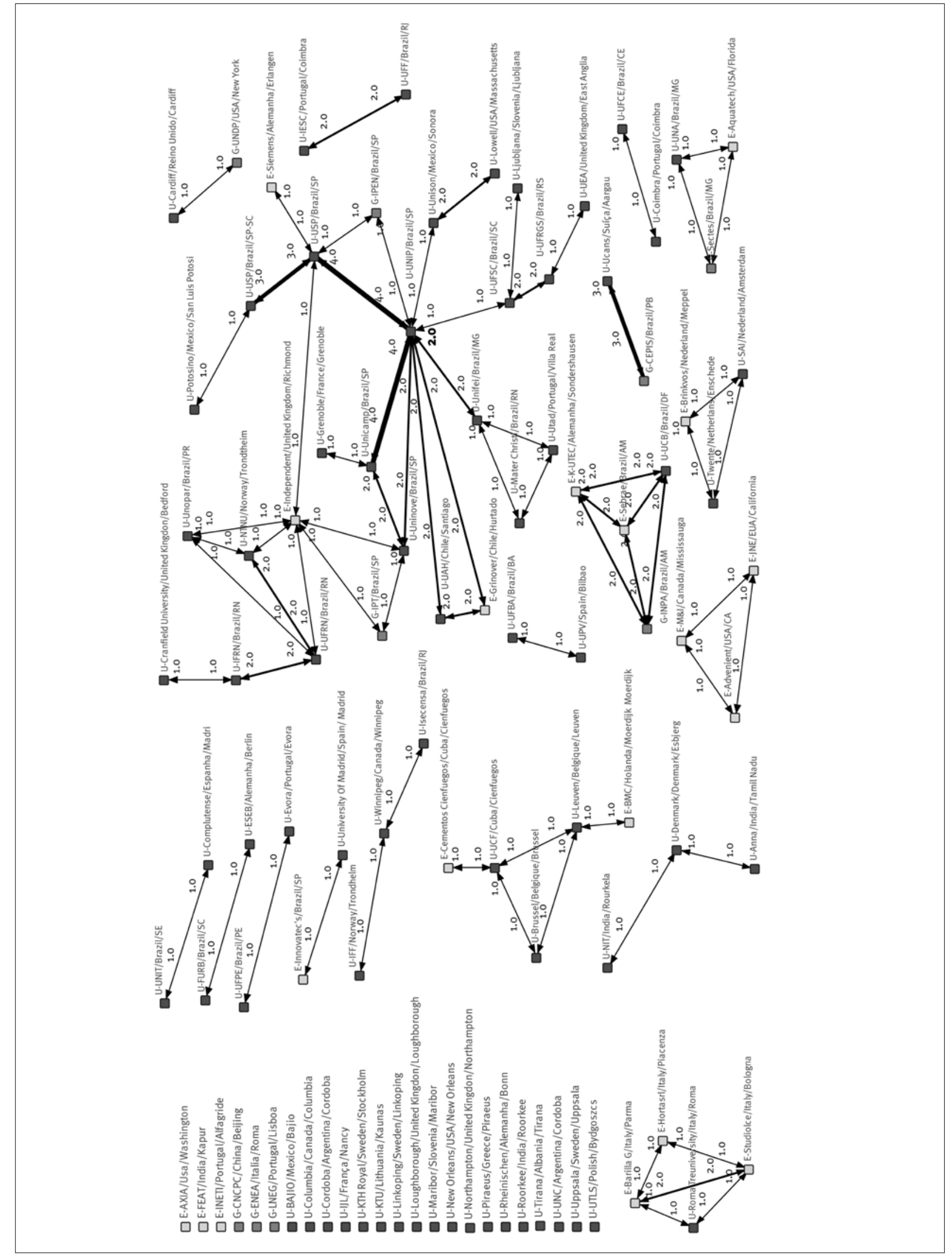


Table 3. Universities, enterprises, and government, and the most relevant relations

\begin{tabular}{|c|c|c|c|c|c|c|c|c|}
\hline \multicolumn{9}{|c|}{ Brazilian institutions } \\
\hline U - Brazilian universities & TR & IR & ER & D & $\mathrm{U}$ & Most relevant relations ${ }^{a}$ & $\mathrm{~T}$ & DC \\
\hline U-UNIP/Brazil/SP (I) & 88 & 48 & 40 & 0.0009 & (I) & U-UNICAMP/Brazil/SP & 4 & 0.106 \\
\hline U-USP/Brazil/SP (II) & 55 & 31 & 24 & 0.0005 & & U-IFSULDEMINAS/Brazil/MG & 4 & 0.106 \\
\hline U-UfSC/Brazil/SC (III) & 39 & 21 & 18 & 0.0004 & & U-USP/Brazil/SP & 4 & 0.106 \\
\hline U-UNICAMP/Brazil/SP (IV) & 32 & 18 & 14 & 0.00031 & & U-UNESP/Brazil/SP & 3 & 0.079 \\
\hline U-UFRGS/Brazil/RS (V) & 15 & 1 & 14 & 0.00021 & & U-Fatec/Brazil/SP & 3 & 0.079 \\
\hline U-UNESP/Brazil/SP (VI) & 33 & 20 & 13 & 0.00039 & & E-Grinover/Chile/Hurtado & 2 & 0.053 \\
\hline U-UTFPR/Brazil/PR (VII) & 18 & 8 & 10 & 0.00029 & & E-Fleury/Brazil/SP & 1 & 0.026 \\
\hline U-UCS/Brazil/RJ (VIII) & 16 & 6 & 10 & 0.00025 & & G-Ipen/Brazil/SP & 1 & 0.026 \\
\hline G - Brazilian governments & TR & IR & ER & D & (II) & U-UNIP/Brazil/SP & 4 & 0.106 \\
\hline G-INPA/Brazil/AM & 6 & 0 & 6 & 0.0001 & & U-USP/Brazil/SP-SC & 3 & 0.079 \\
\hline G-CEPIS/Brazil/PB & 5 & 0 & 5 & 0.00008 & & U-UFTM/Brazil/MG & 2 & 0.053 \\
\hline G-IPEN/Brazil/SP & 14 & 9 & 5 & 0.00008 & & U-UFSCAR/Brazil/SC & 2 & 0.053 \\
\hline G-CETESB/Brazil/SP & 3 & 1 & 2 & 0.00003 & & E-Pinheiro Pedro L./Brazil/SP & 1 & 0.026 \\
\hline G-IPT/Brazil/SP & 5 & 3 & 2 & 0.00003 & & E-Siemens/Germany/Erlangen & 1 & 0.026 \\
\hline G-SECTES/Brazil/MG & 2 & 0 & 2 & 0.00003 & & E-Independent/Uk/Richmond & 1 & 0.026 \\
\hline G-APTA/Brazil/SP & 1 & 0 & 1 & 0.00001 & & G-IPEN/Brazil/SP & 1 & 0.026 \\
\hline G-CDTN/Brazil/RJ & 1 & 0 & 1 & 0.00001 & & G-Cetesb/Brazil/SP & 1 & 0.026 \\
\hline G-IDR/Brazil/PR & 1 & 0 & 1 & 0.00001 & (III) & U-UDESC/Brazil/SC & 3 & 0.079 \\
\hline G-CETEA-Ital/Brazil/SP & 1 & 0 & 1 & 0.00001 & & U-UFRGS/Brazil/RS & 2 & 0.053 \\
\hline G-Eletronuclear/Brazil/RJ & 1 & 0 & 1 & 0.00001 & & U-UFRGS/Brazil/RS & 2 & 0.053 \\
\hline G-Fiocruz/Brazil/RJ & 2 & 1 & 1 & 0.00001 & & U-UTFPR/Brazil/PR & 2 & 0.053 \\
\hline G-Furnas/Brazil/SP & 1 & 0 & 1 & 0.00001 & & U-Univali/Brazil/SC & 2 & 0.053 \\
\hline G-Amar/Brazil/RJ & 1 & 1 & 0 & 0.0000 & (IV) & U-UNIP/Brazil/SP & 4 & 0.106 \\
\hline G-Eletronorte/Brazil/DF & 1 & 1 & 0 & 0.0000 & & U-Uninove/Brazil/SP & 3 & 0.079 \\
\hline G-SABESP/Brazil/SP & 4 & 4 & 0 & 0.0000 & & U-Senac/Brazil/SP & 2 & 0.053 \\
\hline E-Brazilian enterprises & TR & IR & ER & D & & E-CTBE/Brazil/SP & 1 & 0.026 \\
\hline E-Sebrae/Brazil/Am & 6 & 0 & 6 & 0.0001 & $(\mathrm{~V})$ & U-Feevale/Brazil/RS & 2 & 0.053 \\
\hline E-Tecnoambi/Brazil/RS & 3 & 0 & 3 & 0.00008 & & U-UDESC/Brazil/SC & 2 & 0.053 \\
\hline E-Senai/Brazil/RS & 5 & 2 & 3 & 0.00008 & & U-UNIVALI/Brazil/SC & 2 & 0.053 \\
\hline E-CTC/Brazil/SP & 2 & 0 & 2 & 0.00003 & & U-UfSC/Brazil/SC & 2 & 0.053 \\
\hline E-Delmanto Lawyers/Brazil/SP & 2 & 0 & 2 & 0.00003 & & E-Tecnoambi/Brazil/RS & 1 & 0.026 \\
\hline E-Embrapa/Brazil/DF & 2 & 0 & 2 & 0.00003 & & E-Senai/Brazil/RS & 1 & 0.026 \\
\hline E-Figueiredo/Brazil/SP & 2 & 0 & 2 & 0.00003 & $(\mathrm{VI})$ & U-FSP/Brazil/SP & 3 & 0.079 \\
\hline E-Senai/Brazil/CE & 2 & 0 & 2 & 0.00003 & & U-UNIP/Brazil/SP & 3 & 0.079 \\
\hline E-Smart/Brazil/SP & 2 & 0 & 2 & 0.00003 & & E-Delmanto L/Brazil/SP & 1 & 0.026 \\
\hline E-Braskem/Brazil/SP & 1 & 0 & 1 & 0.00001 & $(\mathrm{VII})$ & U-UFSC/Brazil/SC & 2 & 0.053 \\
\hline $\mathrm{E}-\mathrm{CNH} / \mathrm{Brazil} / \mathrm{MG}$ & 1 & 0 & 1 & 0.00001 & & U-UEM/Brazil/PR & 2 & 0.053 \\
\hline E-CTBE/Brazil/SP & 2 & 1 & 1 & 0.00001 & & U-UFPR/Brazil/PR & 2 & 0.053 \\
\hline E-E2/Brazil/MG & 1 & 0 & 1 & 0.00001 & (VIII) & U-FTSG/Brazil/RS & 2 & 0.053 \\
\hline E-Fat/Brazil/SP & 1 & 0 & 1 & 0.00001 & & U-Unipampa/Brazil/RS & 2 & 0.053 \\
\hline E-Firjan/Brazil/RJ & 1 & 0 & 1 & 0.00001 & & E-Tecnoambi/Brazil/RS & 1 & 0.026 \\
\hline E-I3g/Brazil/SC & 1 & 0 & 1 & 0.00001 & & & & \\
\hline E-Klabin/Brazil/SP & 1 & 0 & 1 & 0.00001 & & & & \\
\hline E-Pinheiro Pedro Lawyers/Brazil/SP & 1 & 0 & 1 & 0.00001 & & & & \\
\hline E-Psa/Brazil/SP & 1 & 0 & 1 & 0.00001 & & & & \\
\hline E-Senai/Brazil/BA & 2 & 1 & 1 & 0.00001 & & & & \\
\hline E-Senai/Brazil/RJ & 1 & 0 & 1 & 0.00001 & & & & \\
\hline E-Whirlpool/Brazil/SP & 1 & 0 & 1 & 0.00001 & & & & \\
\hline E-Fleury/Brazil/SP & 1 & 0 & 1 & 0.00001 & & & & \\
\hline E-Innovatec's/Brazil/SP & 1 & 0 & 1 & 0.00001 & & & & \\
\hline E-Rhodia/Brazil/SP & 3 & 3 & 0 & 0.0000 & & & & \\
\hline E-BSH/Brazil/SP & 1 & 1 & 0 & 0.0000 & & & & \\
\hline E-Efil/Brazil/SP & 1 & 1 & 0 & 0.0000 & & & & \\
\hline E-Geosystec/Brazil/SP & 1 & 1 & 0 & 0.0000 & & & & \\
\hline E-Ineti/Portugal/Alfagride & 1 & 1 & 0 & 0.0000 & & & & \\
\hline E-Petrobras/Brazil/RJ & 1 & 1 & 0 & 0.0000 & & & & \\
\hline E-Pinheiro Neto Adv/Brazil/SP & 1 & 1 & 0 & 0.0000 & & & & \\
\hline E-Sebrae/Brazil/RN & 1 & 1 & 0 & 0.0000 & & & & \\
\hline E-Sherwin-William/Brazil/SP & 1 & 1 & 0 & 0.0000 & & & & \\
\hline E-Zinco/Brazil/SP & 1 & 1 & 0 & 0.0000 & & & & \\
\hline
\end{tabular}

E-I3g/Brazil/SC

E-Klabin/Brazil/SP

E-Pinheiro Pedro Lawyers/Brazil/SP

E-Psa/Brazil/SP

E-Senai/Brazil/BA

E-Senai/Brazil/RJ

E-Whirlpool/Brazil/SP

E-Fleury/Brazil/SP

E-Innovatec's/Brazil/SP

E-Rhodia/Brazil/SP

E-BSH/Brazil/SP

E-Efil/Brazil/SP

E-Geosystec/Brazil/SP

E-Ineti/Portugal/Alfagride

E-Petrobras/Brazil/RJ

E-Pinheiro Neto Adv/Brazil/SP

E-Sebrae/Brazil/RN

E-Sherwin-William/Brazil/SP

E-Zinco/Brazil/SP

aniversity - U; Enterprise - E and Government - G. Total Relations - TR; Internal Relations - IR and External Relations - ER 
Table 3. Universities, enterprises, and government, and the most relevant relations

(continuation)

Foreign institutions

\begin{tabular}{|c|c|c|c|c|c|c|c|c|c|}
\hline E- Foreign enterprises & TR & IR & ER & D & $\mathbf{E}$ & $\mathrm{T}$ & Most relevant relations $^{a}$ & $\mathrm{~T}$ & DC \\
\hline E-Independent/UK/Richmond (I) & 10 & 4 & 6 & 0.00019 & (I) & 6 & U-USP/Brazil/SP & 1 & 0.057 \\
\hline E-K-Utec/Germany/Sondershausen (II) & 6 & $\begin{array}{l}4 \\
0\end{array}$ & 6 & 0.00019 & & & U-UFRN/Brazil/RN & 1 & 0.057 \\
\hline E-Barilla G/Italy/Parma (III) & 4 & 0 & 4 & 0.0001 & & & U-Uninove/Brazil/SP & 1 & 0.057 \\
\hline E-Grinover/Chile/Hurtado (IV) & 4 & 0 & 4 & 0.0001 & & & U-NTNU/Norway/Trondtheim & 1 & 0.057 \\
\hline E-Studiolce/Italy/Bologna (V) & 4 & 0 & 4 & 0.0001 & & & U-UNOPAR/Brazil/PR & 1 & 0.057 \\
\hline E-Advenient/USA/CA & 2 & 0 & 2 & 0.00005 & & & G-IPT/Brazil/SP & 1 & 0.057 \\
\hline E-Aquatech/USA/Florida & 2 & 0 & 2 & 0.00005 & (II) & 6 & G-INPA/Brazil/AM & 2 & 0.114 \\
\hline E-Brinkvos/Netherlands/Meppel & 2 & 0 & 2 & 0.00005 & & & U-UCB/Brazil/DF & 2 & 0.114 \\
\hline E-Hortasrl/Italy/Piacenza & 2 & 0 & 2 & 0.00005 & & & G-INPA/Brazil/AM & 2 & 0.114 \\
\hline E-Jne/Usa/California & 2 & 0 & 2 & 0.00005 & (III) & 4 & E-Studiolce/Italy/Bologna & 2 & 0.114 \\
\hline E-M\&l/Canada/Mississauga & 2 & 0 & 2 & 0.00005 & & & E-Hortasrl/Italy/Piacenza & 1 & 0.057 \\
\hline E-Bmc/Netherlands/Moerdijk & 1 & 0 & 1 & 0.00002 & & & U-Roma Treuniversity/Italy/Roma & 1 & 0.057 \\
\hline E-Cementos Cienfuegos/Cuba/Cienfuegos & 1 & 0 & 1 & 0.00002 & (IV) & 4 & U-UAH/Chile/Santiago & 2 & 0.114 \\
\hline E-Siemens/Germany/Erlangen & 1 & 0 & 1 & 0.00002 & & & U-UNIP/Brazil/SP & 2 & 0.114 \\
\hline E-Axia/Usa/Washington & 1 & 1 & 0 & 0.0000 & $(\mathrm{~V})$ & 4 & E-Barilla G/Italy/Parma & 2 & 0.114 \\
\hline E-Feat/India/Kapur & 1 & 1 & 0 & 0.0000 & & & E-Hortasrl/Italy/Piacenza & 1 & 0.057 \\
\hline E-Ineti/Portugal/Alfagride & 1 & 1 & 0 & 0.0000 & & & U-Roma Treuniversity/Italy/Roma & 1 & 0.057 \\
\hline U - Foreign universities & TR & IR & ER & D & $\mathrm{U}$ & $\mathrm{T}$ & Most relevant relations ${ }^{a}$ & $\mathrm{~T}$ & DC \\
\hline U-Ntnu/Norway/Trondtheim (VI) & 4 & 0 & 4 & 0.0001 & $(\mathrm{Vl})$ & 4 & U-UFRN/Brazil/RN & 2 & 0.114 \\
\hline U-UAH/Chile/Santiago (VII) & 4 & 0 & 4 & 0.0001 & & & U-UNOPAR/Brazil/PR & 1 & 0.057 \\
\hline U-Unison/Mexico/Sonora (VIII) & 14 & 11 & 3 & 0.00007 & & & E-Independent/Uk/Richmond & 1 & 0.057 \\
\hline U-UCF/Cuba/Cienfuegos (IX) & 4 & 1 & 3 & 0.00007 & (VIII) & 4 & U-UNIP/Brazil/SP & 2 & 0.114 \\
\hline U-Leuven/Belgique/Leuven $(\mathrm{X})$ & 3 & 0 & 3 & 0.00007 & & & E-Grinover/Chile/Hurtado & 2 & 0.114 \\
\hline U-Linkoping/Sweden/Linkoping (XI) & 3 & 0 & 3 & 0.00007 & (VIII) & 3 & U-Lowell/USA/Massachusetts & 2 & 0.114 \\
\hline U-Ucans/Switzerland/Aargau & 3 & 0 & 3 & 0.00007 & & & U-UNIP/Brazil/SP & 1 & 0.057 \\
\hline U-Brussel/Belgique/Brussel & 3 & 1 & 2 & 0.00005 & $(\mathrm{IX})$ & 3 & U-Brussel/Belgium/Brussel & 1 & 0.057 \\
\hline U-Lowell/USA/Massachusetts & 3 & 1 & 2 & 0.00005 & & & U-Leuven/Belgium/Leuven & 1 & 0.057 \\
\hline U-Denmark/Denmark/Esbjerg & 2 & 0 & 2 & 0.00005 & & & E-Cementos Cienfuegos/Cuba/Cienfuegos & 1 & 0.057 \\
\hline U-IESC/Portugal/Coimbra & 2 & 0 & 2 & 0.00005 & $(\mathrm{X})$ & 3 & E-BMC/Nederlands/Moerdijk & 1 & 0.057 \\
\hline U-Roma Treuniversity/Italy/Roma & 2 & 0 & 2 & 0.00005 & & & U-Brussel/Belgium/Brussel & 1 & 0.057 \\
\hline U-Sai/Netherlands/Amsterdam & 2 & 0 & 2 & 0.00005 & & & U-UCF/Cuba/Cienfuegos & 1 & 0.057 \\
\hline U-Twente/Netherlands/Enschede & 2 & 0 & 2 & 0.00005 & $(\mathrm{XI})$ & 3 & G-CEPIS/Brazil/PB & 3 & 0.172 \\
\hline U-Utad/Portugal/Villa Real & 2 & 0 & 2 & 0.00005 & G & $\mathrm{T}$ & Most relevant relations ${ }^{a}$ & $\mathrm{~T}$ & DC \\
\hline U-Winnipeg/Canada/Winnipeg & 3 & 1 & 2 & 0.00005 & $(\mathrm{XII})$ & 1 & U-Cardiff/UK/Cardiff & 1 & 0.057 \\
\hline U-Cardiff/UK/Cardiff & 2 & 1 & 1 & 0.00002 & (XIII) & 0 & & & \\
\hline U-Anna/India/Tamil Nadu & 1 & 0 & 1 & 0.00002 & (XIV) & 0 & & & \\
\hline U-Coimbra/Portugal/Coimbra & 1 & 0 & 1 & 0.00002 & $(\mathrm{XV})$ & 0 & & & \\
\hline
\end{tabular}

U-Coimbra/Portugal/Coimbra

U-Complutense/Spain/Madri

\begin{tabular}{ll|l|l|l}
\hline U-Cranfield University/UK/Bedford & 1 & 0 & 1 & 0.00002 \\
\hline
\end{tabular}

\begin{tabular}{|l|l|l|l|l|}
\hline U-ESEB/Germany/Berlin & 1 & 0 & 1 & 0.00002 \\
\hline
\end{tabular}

\begin{tabular}{|l|l|l|l|l}
\hline U-Evora/Portugal/Evora & 1 & 0 & 1 & 0.00002 \\
\hline
\end{tabular}

\begin{tabular}{|l|l|l|l|l|}
\hline U-Grenoble/France/Grenoble & 1 & 0 & 1 & 0.00002 \\
\hline
\end{tabular}

\begin{tabular}{l|l|l|l|l|l}
\hline U-IFF/Norway/Trondhelm & 1 & 0 & 1 & 0.00002 \\
\hline
\end{tabular}

\begin{tabular}{|l|l|l|l|l|l}
\hline U-Ljubljana/Slovenia/Ljubljana & 1 & 0 & 1 & 0.00002 \\
\hline
\end{tabular}

\begin{tabular}{|l|l|l|l|l|}
\hline U-NIT/India/Rourkela & 1 & 0 & 1 & 0.00002 \\
\hline
\end{tabular}

\begin{tabular}{l|l|l|l|l}
\hline U-Potosino/Mexico/San Luis Potosi & 1 & 0 & 1 & 0.00002 \\
\hline
\end{tabular}

\begin{tabular}{|l|l|l|l|l|}
\hline U-UEA/UK/East Anglia & 1 & 0 & 1 & 0.00002 \\
\hline
\end{tabular}

\begin{tabular}{l|l|l|l|l}
\hline U-UPV/Spain/Bilbao & 1 & 0 & 1 & 0.00002 \\
\hline
\end{tabular}

\begin{tabular}{|l|l|l|l|l|}
\hline U-University of Madrid/Spain/ Madrid & 1 & 0 & 1 & 0.00002 \\
\hline
\end{tabular}

\begin{tabular}{|l|l|l|l|l|}
\hline U-Bajio/Mexico/Bajio & 2 & 2 & 0 & 0.0000
\end{tabular}

U-KTU/Lithuania/Kaunas

U-New Orleans/USA/New Orleans

U-UNC/Argentina/Cordoba

U-Columbia/Canada/Columbia

U-Cordoba/Argentina/Cordoba

U-IJL/France/Nancy

U-Kth Royal/Sweden/Stockholm

U-Loughborough/UK/Loughborough

U-Maribor/Slovenia/Maribor

U-Piraeus/Greece/Piraeus

U-Rheinischen/Germany/Bonn

U-Roorkee/India/Roorkee

U-Tirana/Albania/Tirana

U-Uppsala/Sweden/Uppsala

U-UTLS/Polish/Bydgoszcs

G - Foreign governments

G-UNDP/USA/New York (XII)

G-CNCPC/China/Beijing (XIII)

G-ENEA/Italy/Roma (XIV)

G-LNEG/Portugal/Lisboa (XV)

aniversity - U; Enterprise - E and Government - G. Total Relations - TR; Internal Relations - IR and External Relations - ER 


\section{Improving the state of research on CP in Brazil}

From the results presented in this research, a framework of research methods, business segments, subjects, universities, enterprises, and government should be proposed to improve the state of CP research. This framework shows the main points concerning the observed CP situation, how to change/improve this situation, and the possible consequences of change and removing barriers to change. This framework is shown in Exhibit 2.

\section{Exhibit 2. Framework of thematics, subjects, research methods, business segments, universities, enterprises, and the government}

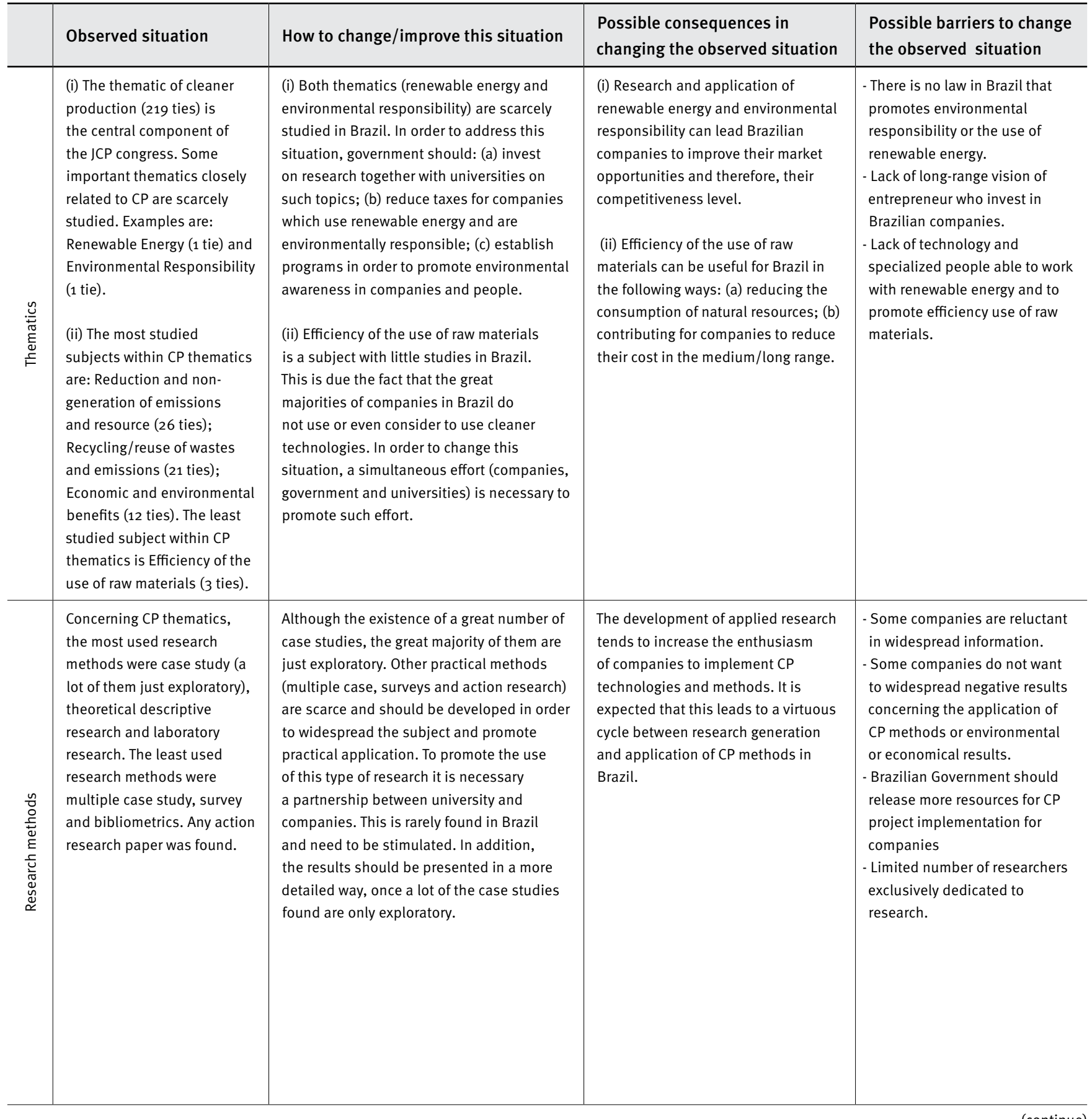


Exhibit 2. Framework of thematics, subjects, research methods, business segments, universities, enterprises, and the government (continuation)

\begin{tabular}{|c|c|c|c|c|}
\hline & Observed situation & How to change/improve this situation & $\begin{array}{l}\text { Possible consequences in } \\
\text { changing the observed situation }\end{array}$ & $\begin{array}{l}\text { Possible barriers to change } \\
\text { the observed situation }\end{array}$ \\
\hline 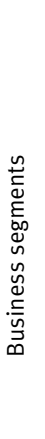 & $\begin{array}{l}\text { Some of the most studied } \\
\text { business segments } \\
\text { within CP were Metal } \\
\text { Mechanics, Building and } \\
\text { Agribusiness. Some of the } \\
\text { least studied were Landfill, } \\
\text { Petrochemicals, Steel, } \\
\text { Mining, Tanneries and } \\
\text { Wooden artifacts. }\end{array}$ & $\begin{array}{l}\text { Some business segments, for its intrinsic } \\
\text { characteristics, are more familiar with } \\
\text { CP. It is necessary to promote CP into the } \\
\text { business segments little studied in the } \\
\text { present research. }\end{array}$ & $\begin{array}{l}\text { The widespread of } \mathrm{CP} \text { to sectors little } \\
\text { studied so far can lead companies } \\
\text { of such business segments to } \\
\text { implement such technologies and } \\
\text { methods. }\end{array}$ & $\begin{array}{l}\text { - Lack of knowledge of } \\
\text { entrepreneurs about } \\
\text { government investments in CP } \\
\text { Technologies, especially for } \\
\text { some sectors. } \\
\text { - Entrepreneurs are not sure } \\
\text { about the benefits of the } \\
\text { adoption of CP technologies } \\
\text { and methods. } \\
\text { - Lack of technology and } \\
\text { specialized people able to work } \\
\text { with CP. }\end{array}$ \\
\hline
\end{tabular}




\section{CONCLUSIONS}

This study presents a bibliometric review and network analysis of articles published from the congresses in 2007, 2009, 2011, and 2013. The main goal of the study is to present and contribute to improving the current state of $\mathrm{CP}$ research in Brazil.

First, we examined the thematics, subjects, business segments, and research methods studied in the JCP congress. Then, the affiliations (universities, government, enterprises, and countries) of the authors that participated in the four editions of the events were presented. In addition, the relationships among these constructs were elaborated upon. From these results, a framework was proposed. This framework (see Exhibit 2) shows the observed CP situation for the constructs, how to change/ improve this situation, the possible and the consequences of changing this situation and removing barriers to change.

Based on this framework, we conclude that many thematics and subjects related to $\mathrm{CP}$ deserve more attention in Brazil. The adoption of CP by Brazilian companies has greater asymmetry with environmental education, environmental management systems, and ISO 14001, aimed primarily at reducing energy, water, and waste and solid waste management. However, there is little research on renewable energy and environmental responsibility, showing that opportunities exist for research and contributions on sustainable development. Moreover, the results indicated that the implementation of CP should be disseminated to various Brazilian business segments as a means of enhancing sustainable development.

While there are many remarkable accomplishments in the development of CP practices in Brazil, this is still only a trend. In general, to intensify CP in Brazilian companies we suggest improving the communication channels among government, enterprises, universities, and society in order to exchange experiences. In this way, shareholders and entrepreneurs will learn about the subsidies/funds to implement CP, allowing greater adherence to the implementation of CP practices. Moreover, universities, through their research programs, may help companies in their research, enabling innovation in terms of implementation and scientific methods. There is a need for more applied research, for instance, action research in operational reality to generate innovations. Therefore, society would be more educated, allowing for a continuous cycle of learning.

Consequently, one should not think of sustainable development through $\mathrm{CP}$, without considering the stakeholders (government, enterprises, universities, and society). Development will only occur if the process is genuine and integrated. Note that in this process all stakeholders may benefit. Thus, sustainable public policies could be a reference and serve as a benchmark for other countries. Companies may minimize costs by reducing waste and still reduce their environmental impact, which can lead to more attractive investments and an enhanced competitive advantage. Brazilian universities could generate more innovation and promote internationalization and society that recognizes environmental education as a means of survival for future generations.

However, developing countries (e.g., Brazil) have serious difficulties in developing a government system with CP laws because of the central focus on improving gross domestic production as a matter of survival and that projects related to sustainable production and consumption are still trends in character.

Such research has the potential for companies and the country to contribute to increasing their competitiveness level, manufacturing products in a sustainable way. Such research is mandatory to establish a relationship among Brazilian universities, government, and enterprises, as well as among these and foreign institutions.

The Brazilian government should create laws specifically directed at sustainable production and consumption, which incentivizes and supports the development of such research. Finally, CP funding analyses and policy priorities are being turned into scientific priorities and scientific results (Vasileiadou, Heimeriks, \& Petersen, 2011).

This study provides the basis for future research, even though bibliometric methods have their limitations, according to Ferreira, Pinto, and Serra (2013). However, the evolution of research is a cumbersome work and requires considering both objective and subjective aspects (Tahira, Alias, \& Bakri, 2013).

\section{REFERENCES}

Ávila, L. V., Madruga, L. R. R. G., Zamberlan, J. F., \& Barros, I. C. F. (2013). Água e sustentabilidade: Um levantamento da produção científica e dos hot topics publicados na última década. Engenharia Ambiental Espirito Santo do Pinhal, 10(2), 3-21.

Bakker, F. G. A., Groenewegen, A. P., \& Hond, F. D. (2005). A bibliometric analysis of 30 years of research and theory on corporate social responsibility and corporate social performance. Business \& Society, 44(3), 283-317. doi:10.1177/0007650305278086

Bardin, L. (1986). El análisis de contenido. Madrid, Spain: Ediciones Akal.

Barrios, M., Borrego, A., Vilaginés, A., Ollé, C., \& Somoza, M. (2008). A bibliometric study of psychological research on tourism. Scientometrics, 77(3), 453-467. doi:10.1007/s11192-007-1952-0

Boks, C., Stevels, A., \& Koster, J. (2001). The impact of literature references in the field of applied ecodesign. International Symposium on Environmentally conscious Design and Inverse Manufacturing. 
Borgatti, S.P. (2002). Net Draw: Graph visualization software. Harvard, USA: Analytic Technologies.

Brito, R. P., \& Berardi, P. C. (2010). Vantagem competitiva na gestão sustentável da cadeia de suprimentos: Um metaestudo. RAE-Revista de Administração de Empresas, 50(2), 155-169. doi:10.159o/soo3475902010000200003

Chai, K., \& Xiao, X. (2012). Understanding design research: A bibliometric analysis of design studies (1996 e 2010). Design Studies, 33(1), 2443. doi:10.1016/j.destud.2011.06.004

Chang, I. S., Wu, J., Qiao, H., \& Zhang, Z. (2015). The spatio-temporal approach to regional analysis on cleaner production in China. Renewable and Sustainable Energy Reviews, 52, 1491-1503. doi:10.1016/j.rser.2015.07.180

Chen, L., Tang, O., \& Feldmann, A. (2015). Applying GRI reports for the investigation of environmental management practices and company performance in Sweden, China and India. Journal of Cleaner Production, 98(1), 36-46. doi:10.1016/j.jclepro.2014.02.001

Cooper, H. M., \& Lindsay, J. L. (1998). Research synthesis and metaanalysis. In: L. Beckman, D. J. R. (Eds), Handbook of applied social research methods. Thousand Oaks, USA: Sage.

Costa, G.S., \& Boente, D.R. (2012). Análise do perfil da produção científica sobre ciclo de vida no período de 2000 a 2011. Revista Ambiente, 4(1), 106-119.

De Nooy, W., Mrvar, A., \& Batagelj, V. (2005). Exploratory social network analysis with Pajek. New York, USA: Cambridge University Press.

Deng, W., Chen, D., Huang, M., Hu, J., \& Chen, L. (2015). Carbon dioxide deliming in leather production: A literature review. Journal of Cleaner Production, 87(15), 26-38. doi:10.1016/j.jclepro.2014.09.066

Du, H., Wei, L., Brown, M. A., Wang, Y., \& Shi, Z. (2013). A bibliometric analysis of recent energy efficiency literatures: An expanding and shifting focus. Energy Efficiency, 6(1), 177-190. doi:10.1007/s12053012-9171-9

Ferreira, M. P., Pinto, C. F., \& Serra, F. R. (2013). The transaction costs theory in international business research: A bibliometric study over three decades. Scientometrics. doi:10.1007/s11192-013-1172-8.

García, V., Pongrácza, E., Phillips, P. S., \& Keiski, R. L. (2013). From waste treatment to resource efficiency in the chemical industry: Recovery of organic solvents from waters containing electrolytes by per vaporation. Journal of Cleaner Production, 39, 146-153. doi:10.1016/j. jclepro.2012.08.020

Giannetti, B. F., Ogura, Y., Bonilla, S. H., \& Almeida, C. M. V. B. (2012). Accounting emergy flows to determine the best production model of a coffee plantation. Energy Policy, 39(11), 7399-7407. doi:10.1016/j. enpol.2011.09.005

Glavič, P., \& Lukman, R. (2007). Review of sustainability terms and their definitions. Journal of Cleaner Production, 15(18), 1875-1885. doi:10.1016/j.jclepro.2006.12.006

Hanneman, R. A., \& Riddle, M. (2005). Introduction to social network methods. Riverside, USA: University of California.

Hayes, A. F., \& Krippendorff, K. (2007). Answering the call for a standard reliability measure for coding data. Communication Methods and Measures, 1(1), 77-89. doi:10.1080/19312450709336664

Hassan, S., Haddawy, P., \& Zhu, J. (2013). A bibliometric study of the world's research activity in sustainable development and its subareas using scientific literature. Scientometrics, 99(2), 549-579. doi:10.1007/s11192-013-1193-3.
Hoejmose, S.U., \& Adrien-Kirby, A.J. (2012). Socially and environmentally responsible procurement: A literature review and future research agenda of a managerial issue in the 21st century. Journal of Purchasing \& Supply Management, 18(4), 232-242. doi:10.1016/j. pursup.2012.06.002

Hu, J., \& Deng, W. (2016). Application of supercritical carbon dioxide for leather processing. Journal of Cleaner Production, 113(1), 931-946. doi:10.1016/j.jclepro.2015.10.104

International Workshop Advances in Cleaner Production. (2007). The role of cleaner production in the sustainable development of modern societies. Conference Proceedings. 1-166.

International Workshop Advances in Cleaner Production. (2009). Key elements for a sustainable world energy, water and climate change. Conference Proceedings. 1-215.

International Workshop Advances in Cleaner Production. (2011). Cleaner production initiatives and challenges for a sustainable world. Conference Proceedings. 1-276.

International Workshop Advances in Cleaner Production. (2013). Integrating cleaner production into sustainable strategies. Conference Proceedings. 1-260.

Karatzoglou, B. (2013). An in-depth literature review of the evolving roles and contributions of universities to education for sustainable development. Journal of Cleaner Production, 49, 44-53.

Jung, J. J. (2011). A bibliometric analysis on green supply chain management: A preliminary result. In: IEEE Conference on Commerce and Enterprise Computing, Luxembourg.

Khan, Z. (2008). Cleaner production: An economical option for ISO certification in developing countries. Journal of Cleaner Production, 16(1), 22-27. doi:10.1016/j.jclepro.2006.06.007

Kim, Y., Choi, T. Y., Yan, T., \& Dooley, K. (2011). Structural investigation of supply networks: A social network analysis approach. Journal of Operations Management, 29(3), 194-211. doi:10.1016/j. jom.2010.11.001

Kneipp, J. M., Rosa, L. A. B., Bichueti, R. S., Madruga, L. R. R. M., \& Schuch., V. F. (2011). Emergency of the sustainable innovation thematic: An analysis of scientific production through Web of Science base. Revista de Administração da UFSM, 4(3), 442-457. doi:10.5902/198346593755

Leonidou, C. N., \& Leonidou, L. C. (2011). Research into environmental marketing/management: A bibliographic analysis. European Journal of Marketing, 45(1-2), 68-103. doi:10.1108/03090561111095603

Machado, C. G., Manfrin, P. M., Lima, E. P., Silva, W. V., \& Maciel, C. O. (2012). Sustainability operations management: An overview of research trends. In G. Lim \& J. W. Herrmann, Proceedings of the 2012 Industrial and Systems Engineering Research Conference.

Pereira, G. R., \& Sant’Anna, F.S.P. (2012). Uma análise da produção mais limpa no Brasil. Revista Brasileira de Ciências Ambientais, (24), 17-26.

Pilkington, A., \& Meredith, J. (2009). The evolution of the intellectual structure of operations management - 1980-2006: A citation/cocitation analysis. Journal of Operations Management, 27(3), 185-202. doi:10.1016/j.jom.2008.08.001

Política Nacional de Resíduos Sólidos. (2010). Política Nacional de Resíduos Sólidos. Lei № 12.305/2010. Retrieved from http://www. planalto.gov.br/ccivil_03/_at02007-2010/2010/lei/l12305.htm.

Radosevic, S. (2008). A review of a literature on innovation, with a focus on policy and institutional implications. Paper prepared for the World Bank and presented at Globelics/Prime Conference, Mexico City. 
Riaz, A., Zahedi, G., \& Klemeš, J. J. (2013). A review of cleaner production methods for the manufacture of methanol. Journal of Cleaner Production, 57(15), 19-37. doi:10.1016/j.jclepro.2013.06.017

Romo-Fernández, L. M., Guerrero-Bote, V. P., \& Moya-Anegón, F. (2012). World scientific production on renewable energy, sustainability and the environment. Energy for Sustainable Development, 16(4), 500508. doi:10.1016/j.esd.2012.06.005

Rocha, A. C. R., Camargo, C. R., Kneipp, J. M., Ávila, L. V., Gomes, C. M., \& Madruga, L. R. R. G. (2012b). Gestão para a sustentabilidade na indústria mineral: Um levantamento da produção científica e dos hot topics publicados na última década. Revista Estudos do CEPE, (36), 228-251.

Rocha, A. C., Rosa, L. B., Camargo, C. R., Zamberlan, J. F., \& Gomes, C. M. (2013). Gestão da cadeia de suprimentos e sustentabilidade: Um estudo bibliométrico da produção científica na base Web of Science. Revista Brasileira de Administração Científica, 4(1), 155-170. doi:10.6008\%2fess2179-684x.2013.001.0010

Rosa, F. S., Ensslin, S. R., Ensslin, L., \& Lunkes, R.J. (2012a). Environmental disclosure management: A constructivist case. Management Decision, 5o(6), 1117-1136. doi:10.1108/00251741211238364

Rosa, F. S., Lunkes, R. J., Pfitscher, E. D., Feliu, V. R., \& Soler, C. C. (2012b). Contabilidad medioambiental en España: Proceso estructurado de revisión y análisis teórico referencial. Contabilidad y Negocios, 7(14), 23-48.

Sangwan, K. S., \& Mittal, V. K. (2015). A bibliometric analysis of green manufacturing and similar frameworks. Management of Environmental Quality: An International Journal, 26(4), 566-587. doi:10.1108/MEQ-02-2014-0020

Scott, J. (2000). Social network analysis: A handbook. London, UK: Sage Publications.

Silva, M. C., Teixeira, A. A. C. (2011). A bibliometric account of the evolution of EE in the last two decades: Is ecological economics (becoming) a post-normal science? Ecological Economics, 70 (5), 849862. doi:10.1016/j.ecolecon.2010.11.016

Staniškis, J. K. (2012). Sustainable consumption and production: How to make it possible. Clean Technologies and Environmental Policy, 14(6), 1015-1022. doi:10.1007/s10098-012-0535-9
Tahira, M., Alias, R. A., \& Bakri, A. (2013). Scientometric assessment of engineering in Malaysians universities. Scientometrics, 96(3), 865879. doi:10.1007/s11192-013-0961-4

Taticchi, P., Tonelli, F., \& Pasqualino, R. (2013). Performance measurement of sustainable supply chains: A literature review and a research agenda. International Journal of Productivity and Performance Management, 62(8), 782-804. doi:10.1108/IJPPM-03-2013-0037

United Nations Industrial Development Organization. (2015). Retrieved from http://www.unido.org/en/what-we-do/environment/resourceefficient-and-low-carbon-industrial-production/cp/cleanerproduction.html.

Vasileiadou, E., Heimeriks, G., \& Petersen, A. C. (2011). Exploring the impact of the IPCC Assessment Reports on science. Environmental Science \& Policy, 14(8), 1052-1061. doi:10.1016/j.envsci.2011.07.002

Vieira, L. C., \& Amaral, F. G. (2016). Barriers and strategies applying Cleaner Production: A systematic review. Journal of Cleaner Production, 113(1), 5-16. doi:10.1016/j.jclepro.2015.11.034

Yanhua, Z., Song, H., Hongyan, L., \& Beibei, N. (2011). Global Environmental impact assessment research trends (1973-2009). Procedia Environmental Sciences, 11, 1499-1507. doi:10.1016/j. proenv.2011.12.226

Yarime, M., Takeda, Y., \& Kajikawa, Y. (2010). Towards institutional analysis of sustainability science: A quantitative examination of the patterns of research collaboration. Sustainability Science, 5(1), 115125. doi:10.1007/s11625-009-0090-4

Wasserman, S., \& Faust, K. (1994). Social network analysis: Methods and applications. Cambridge, UK: Cambridge University Press.

Watts, D. J., \& Strogatz, S.H. (1998). Collective dynamics of 'small-world' networks. Nature, (393), 440-444. doi:10.1038/30918

Wright, T., \& Pullen, S. (2007). Examining the literature: A bibliometric study of ESD journal articles in the Education Resources Information Center Database. Journal of Education for Sustainable Development, 1(1), 77-90. doi:10.1177/097340820700100114 